\title{
A Window into Africa's Past Hydroclimates: The SISAL_v1 Database Contribution
}

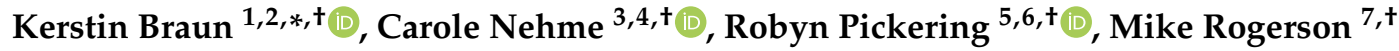 \\ and Nick Scroxton $8,9,+$ (D) \\ 1 Institute of Human Origins, School of Human Evolution and Social Change, Arizona State University, \\ Tempe, AZ 85281, USA \\ 2 African Centre for Coastal Paleoscience, Nelson Mandela University, Port Elizabeth 6031, South Africa \\ 3 Department of Geography, IDEES 6266 CNRS, University of Rouen-Normandy, 76821 Mont Saint-Aignan, \\ France; carole.nehme@univ-rouen.fr \\ 4 Analytical, Environmental \& Geo-Chemistry, Department of Chemistry, Vrije Universiteit Brussel, \\ 1050 Brussel, Belgium \\ 5 Department of Geological Sciences, University of Cape Town, Cape Town 7701, South Africa; \\ robyn.pickering@uct.ac.za \\ 6 Human Evolution Research Institute, University of Cape Town, Cape Town 7701, South Africa \\ 7 School of Environmental Sciences, University of Hull, HU6 7RX Hull, UK; M.Rogerson@hull.ac.uk \\ 8 Department of Geosciences, University of Massachusetts Amherst, Amherst, MA 01003, USA; \\ nscroxton@umass.edu \\ 9 Department of Earth, Atmospheric and Planetary Sciences, Massachusetts Institute of Technology, \\ Cambridge, MA 02139, USA \\ * Correspondence: kbraun2@asu.edu; Tel.: +1-480-965-1077 \\ + All authors contributed equally and are listed alphabetically.
}

Received: 30 September 2018; Accepted: 8 January 2019; Published: 23 January 2019

\begin{abstract}
Africa spans the hemispheres from temperate region to temperate region and has a long history of hominin evolution. Although the number of Quaternary palaeoclimatic records from the continent is increasing, much of the history of spatial and temporal climatic variability is still debated. Speleothems, as archives of terrestrial hydroclimate variability, can help reveal this history. Here we review the progress made to date, with a focus on the first version of the Speleothem Isotopes Synthesis and AnaLysis (SISAL) database. The geology of Africa has limited development of large karst regions to four areas: along the northern coast bordering the Mediterranean, eastern Africa and the Horn of Africa, southwestern Africa and southern Africa. Exploitation of the speleothem palaeoclimate archives in these regions is uneven, with long histories of research, e.g., in South Africa, but large areas with no investigations such as West Africa. Consequently, the evidence of past climate change reviewed here is irregularly sampled in both time and space. Nevertheless, we show evidence of migration of the monsoon belt, with enhanced rainfall during interglacials observed in northeast Africa, southern Arabia and the northern part of southern Africa. Evidence from eastern Africa indicates significant decadal and centennial scale rainfall variability. In northwestern and southern Africa, precession and eccentricity influence speleothem growth, largely through changing synoptic storm activity.
\end{abstract}

Keywords: speleothem; hydroclimate; monsoon; ITCZ; SISAL; oxygen isotopes

\section{Introduction}

Speleothems are secondary cave carbonates and provide valuable archives of past hydroclimates. In this review, we focus on the speleothem record from Africa, using the Speleothem Isotopes Synthesis 
and AnaLysis version 1 database (hereafter, SISAL_v1) [1,2] as a starting point. We include southern Arabia and Madagascar as part of the African region. Africa covers an area of over 30 million $\mathrm{km}^{2}$ and makes up $20 \%$ of the Earth's land surface. It is also the only continent to stretch from the northern temperate to the southern temperate zones, which should theoretically allow an exploration of latitudinal migrations of climatic belts. However, the density of speleothem records is much smaller than in other regions. The paucity of records is partly due to the underlying bedrock geology, which is dominated by Precambrian basement rocks, with little outcrop of carbonates or evaporites (Figure 1) [3]. Drylands and deserts cover $60 \%$ of Africa's land surface [4], which reduces the potential for formation and preservation of speleothem records.

Africa has a long history of speleothem research, with some of the earliest speleothem studies conducted in South Africa [5,6]. Early research focused on South Africa but from the early 2000s onwards, speleothem studies come from across the continent (Figure 1). While some of the early records were dated using radiocarbon [6], the majority of samples are dated with uranium-thorium dating. The advent of uranium-lead dating of speleothems [7] saw the direct dating of the early hominin cave sites in South Africa [8,9] and while these deposits have great potential as archives of past hydroclimates $[10,11]$ they are virtually untapped.

In this paper, we use the SISAL_v1 (Figure 1) as a starting point to explore the speleothem record of the African continent, southern Arabia and Madagascar, focusing on regional trends, connections between the regions, and changes in hydroclimate. We present an overview of the 59 speleothem records from the region, of which 19 are in SISAL_v1 (Table 1). We assess their key findings, provide regional syntheses of the results and outline some key research questions that should frame future research.

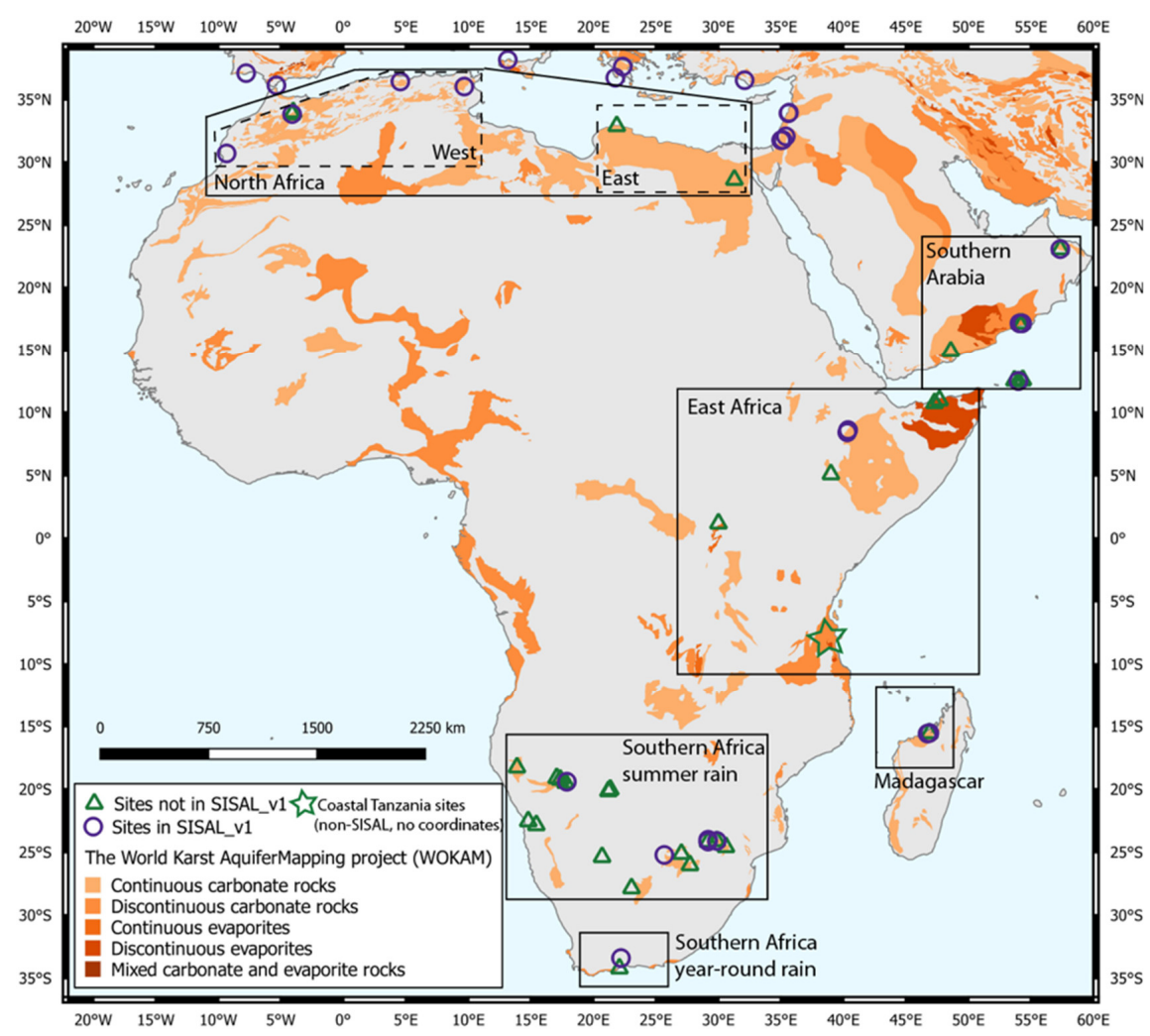

Figure 1. A map of Africa, including Madagascar and southern Arabia, highlighting the distribution of karst regions through the mapping of carbonates and evaporites (data provided by The World Karst Aquifer Mapping Project (WOKAM) [3]) and the locations of speleothem records (open circles represent those included in SISAL_v1; triangles represent sites not included in SISAL_v1). 
Table 1. List of speleothem records from Africa. Column headings in italics represent field names that can be searched in SISAL_v1. Entities without a SISAL_v1 entity_id are not included in the database. Minimum and maximum years refer to minimum and maximum ages of the stable isotopic records (which may be extrapolated from measured dates); minimum and maximum ages in italics are measured values in records where age models for records were not easily accessible, asterisks mark minimum and maximum ages at sites where speleothem dating was used in presence/absence studies or to date archaeological deposits-these records often have no isotope records or no continuous age models if such records were analysed. mamsl = metres above mean sea level, $\mathrm{BP}=\mathrm{before}$ present, where present is defined as 1950 .

\begin{tabular}{|c|c|c|c|c|c|c|c|c|c|c|}
\hline site_name & site_id & Country & $\begin{array}{l}\text { Latitude } \\
\text { (N) }\end{array}$ & $\begin{array}{l}\text { Longitude } \\
\text { (E) }\end{array}$ & $\begin{array}{c}\text { Elevation } \\
(\mathrm{m} \text { amsl) }\end{array}$ & entity_name & entity_id & $\begin{array}{l}\text { Min. Year } \\
\text { (BP) }\end{array}$ & $\begin{array}{l}\text { Max. Year } \\
\text { (BP) }\end{array}$ & Reference \\
\hline Achere Cave & 114 & Ethiopia & 8.60 & 40.37 & 1534 & Ach-1 & 229 & 4523 & 4968 & [12] \\
\hline Aigamas & & Namibia & -19.11 & 17.07 & & & & $112,000 *$ & 129,900 * & [13] \\
\hline Aikab & & Namibia & -19.11 & 17.07 & & & & $7500^{*}$ & 10,600 * & [13] \\
\hline \multirow{6}{*}{ Anjohibe Cave } & \multirow{6}{*}{94} & \multirow{6}{*}{ Madagascar } & \multirow{6}{*}{-15.53} & \multirow{6}{*}{46.88} & \multirow{6}{*}{131} & AB3 & 187 & -64 & 1673 & [14] \\
\hline & & & & & & $\mathrm{AB} 2$ & 188 & -64 & 1343 & [15] \\
\hline & & & & & & MA3 & 189 & 650 & 1580 & [16] \\
\hline & & & & & & ANJB-2 & 190 & 141 & 9027 & [17] \\
\hline & & & & & & MA1 & & -45 & 3412 & [18] \\
\hline & & & & & & MA2 & & -45 & 7340 & [18] \\
\hline Anjokipoty Cave & 32 & Madagascar & -15.58 & 46.73 & $\sim 40$ & MAJ-5 & 107 & 183 & 9880 & [19] \\
\hline Bero Cave & 33 & Ethiopia & 8.42 & 40.31 & 1363 & Bero-1 & 108 & -55 & 7750 & [20] \\
\hline Bone Cave & & Botswana & -20.14 & 21.21 & 1000 & BC97-14 & & -47 & 273 & [21] \\
\hline Buffalo Cave & 148 & South Africa & -24.14 & 29.18 & 1140 & $\begin{array}{l}\text { Buffalo Cave } \\
\text { Flowstone }\end{array}$ & 323 & $1,517,550$ & $1,989,850$ & {$[10,11]$} \\
\hline Cango Cave & 74 & South Africa & -33.39 & 22.21 & $\sim 700$ & V3 & 163 & 41 & 47,978 & {$[5,22,23]$} \\
\hline Casecas Cave & & Yemen & 12.56 & 54.31 & 542 & STM5 & & 12 & 856 & [24] \\
\hline \multirow{5}{*}{ Cold Air Cave } & \multirow{5}{*}{7} & \multirow{5}{*}{ South Africa } & \multirow{5}{*}{-24} & \multirow{5}{*}{29.18} & \multirow{5}{*}{1420} & T5 & 45 & 466 & 4379 & [25] \\
\hline & & & & & & T7_1999 & 46 & -46 & 2506 & {$[26,27]$} \\
\hline & & & & & & T7_2001 & 47 & -46 & 6406 & [28] \\
\hline & & & & & & T8 & 48 & -48 & 24,380 & [29] \\
\hline & & & & & & T7_2013 & 49 & -46 & 314 & [13] \\
\hline Crevice Cave & & South Africa & -34.21 & 22.09 & 15 & composite record & & 53,060 & 90,500 & [30] \\
\hline \multirow{2}{*}{ Dante Cave } & \multirow{2}{*}{99} & \multirow{2}{*}{ Namibia } & \multirow{2}{*}{-19.4} & \multirow{2}{*}{17.88} & & DP1_2013 & 197 & 18 & 4618 & [31] \\
\hline & & & & & & DP1_2016 & 198 & 11 & 487 & [32] \\
\hline
\end{tabular}


Table 1. Cont

\begin{tabular}{|c|c|c|c|c|c|c|c|c|c|c|}
\hline site_name & site_id & Country & $\begin{array}{l}\text { Latitude } \\
\text { (N) }\end{array}$ & $\begin{array}{l}\text { Longitude } \\
\text { (E) }\end{array}$ & $\begin{array}{c}\text { Elevation } \\
\text { (m amsl) }\end{array}$ & entity_name & entity_id & $\begin{array}{l}\text { Min. Year } \\
\text { (BP) }\end{array}$ & $\begin{array}{l}\text { Max. Year } \\
\text { (BP) }\end{array}$ & Reference \\
\hline \multirow{2}{*}{ Defore Cave } & \multirow{2}{*}{170} & \multirow{2}{*}{ Oman } & \multirow{2}{*}{17.17} & \multirow{2}{*}{54.08} & \multirow{2}{*}{150} & S3 & 366 & -46 & 731 & [33] \\
\hline & & & & & & S4 & & 9020 & 10,864 & [34] \\
\hline Dimarshim Cave & & Yemen & 12.55 & 53.68 & 350 & D1 & & -50 & 4400 & [34] \\
\hline Dragons-breath & & Namibia & -19.48 & 17.79 & & & & & $8800^{*}$ & [13] \\
\hline \multirow{6}{*}{$\begin{array}{l}\text { Drotsky's Cave } \\
\text { (Gcwihaba Caves) }\end{array}$} & & \multirow{6}{*}{ Botswana } & \multirow{6}{*}{-20.02} & \multirow{6}{*}{21.36} & & & & $750^{*}$ & $41,900 *$ & [35-37] \\
\hline & & & & & & Stalagmite 1 & & $14,125^{*}$ & $16,190 *$ & [38] \\
\hline & & & & & & Stalagmite 2 & & $3663 *$ & $5860^{*}$ & [37] \\
\hline & & & & & & Stalagmite 3 & & $1185^{*}$ & $5375^{*}$ & [37] \\
\hline & & & & & & $1.0 \mathrm{~m}$ core & & $197,400^{*}$ & & [39] \\
\hline & & & & & & $0.5 \mathrm{~m}$ core & & $5360 *$ & $14,520 *$ & [39] \\
\hline Echo Cave & & South Africa & -24.58 & 30.61 & 1030 & & & $2675 *$ & $231,900 *$ & {$[13,28]$} \\
\hline Gaalweyte Cave & & Somalia & 10.98 & 47.69 & & & & $5000 *$ & $75,500^{*}$ & [13] \\
\hline Gladysvale Cave & & South Africa & -25.12 & 27.05 & & & & $7450 *$ & $571,380 *$ & [40] \\
\hline Goda Mea Cave & & Ethiopia & 9.48 & 37.66 & 1574 & GM1 & & 108,173 & 141,786 & [41] \\
\hline Grotte de Piste & 135 & Morocco & 33.84 & -4.09 & 1260 & GP2 & 285 & 2537 & 11,416 & [42] \\
\hline \multirow{2}{*}{$\begin{array}{l}\text { Grotte Prison de } \\
\text { Chien }\end{array}$} & & \multirow{2}{*}{ Morocco } & \multirow{2}{*}{34} & \multirow{2}{*}{-4} & \multirow{2}{*}{360} & HK1 & & 18,870 & 36,470 & [43] \\
\hline & & & & & & HK3 & & 4240 & 27,480 & [43] \\
\hline \multirow{2}{*}{ Gueldaman Cave } & \multirow{2}{*}{81} & \multirow{2}{*}{ Algeria } & \multirow{2}{*}{36.43} & \multirow{2}{*}{4.57} & \multirow{2}{*}{507} & stm2 & 173 & 4039 & 6191 & [44] \\
\hline & & & & & & stm4 & 174 & 3193 & 5793 & [44] \\
\hline Guinas Meer & & Namibia & -19.23 & 17.35 & & & & $13,500 *$ & $61,400^{*}$ & [13] \\
\hline Harasib & & Namibia & -19.48 & 17.79 & & & & $8500 *$ & 107,600 * & [13] \\
\hline Hayla Cave & & South Africa & 10.76 & 47.30 & 1800 & & & $4000 *$ & 260,400 * & {$[39,40]$} \\
\hline \multirow{3}{*}{ Hoq Cave } & & \multirow{3}{*}{ Yemen } & \multirow{3}{*}{12.59} & \multirow{3}{*}{54.35} & \multirow{3}{*}{335} & STM1 & & -17 & 5717 & [24] \\
\hline & & & & & & STM6 & & 777 & 4608 & [24] \\
\hline & & & & & & $\mathrm{Hq} 1$ & & 146 & 7708 & [24] \\
\hline
\end{tabular}


Table 1. Cont

\begin{tabular}{|c|c|c|c|c|c|c|c|c|c|c|}
\hline site_name & site_id & Country & $\begin{array}{l}\text { Latitude } \\
\text { (N) }\end{array}$ & $\begin{array}{l}\text { Longitude } \\
\text { (E) }\end{array}$ & $\begin{array}{c}\text { Elevation } \\
(\mathrm{m} \text { amsl) }\end{array}$ & entity_name & entity_id & $\begin{array}{l}\text { Min. Year } \\
\text { (BP) }\end{array}$ & $\begin{array}{l}\text { Max. Year } \\
\text { (BP) }\end{array}$ & Reference \\
\hline \multirow{10}{*}{ Hoti Cave } & \multirow{10}{*}{152} & \multirow{10}{*}{ Oman } & \multirow{10}{*}{23.08} & \multirow{10}{*}{57.35} & \multirow{10}{*}{800} & H5 & 327 & 6026 & 9607 & [45] \\
\hline & & & & & & $\mathrm{H} 5$ & & 6220 & 10,760 & {$[34,46]$} \\
\hline & & & & & & H12 & & 230 & 6341 & {$[34,47]$} \\
\hline & & & & & & Flowstone & & 82,000 & 125,700 & {$[47,48]$} \\
\hline & & & & & & $\mathrm{H} 4$ & & 112,900 & 121,600 & {$[47,48]$} \\
\hline & & & & & & H1 & & 77,620 & 82,460 & {$[47]$} \\
\hline & & & & & & H10 & & 8250 & 10,150 & [47] \\
\hline & & & & & & H11 & & 8130 & 9060 & [47] \\
\hline & & & & & & H13 & & 124,000 & 387,000 & [47] \\
\hline & & & & & & H14 & & 6410 & 8470 & [47] \\
\hline Ifoulki Cave & 42 & Morocco & 30.71 & -9.33 & 1250 & IFK1 & 188 & -3 & 1160 & [49] \\
\hline Kiomoni Quarry Cave & & Tanzania & & & & & & $17,430 *$ & $19,270 *$ & [50] \\
\hline La Mine Cave & 83 & Tunisia & 36.03 & 9.68 & 975 & Min-stm1 & 176 & 5366 & 23,168 & [51] \\
\hline \multirow{2}{*}{ Lobatse Cave } & \multirow{2}{*}{30} & \multirow{2}{*}{ Botswana } & \multirow{2}{*}{-25.21} & \multirow{2}{*}{25.68} & \multirow{2}{*}{1200} & LII4 & 103 & 21,425 & 27,206 & {$[52,53]$} \\
\hline & & & & & & LII4-KH & 104 & 21,458 & 50,943 & {$[52,53]$} \\
\hline Mafuriko Quarry & & Tanzania & 5.10 & 39.00 & & & & $28,100^{*}$ & $39,400 *$ & {$[50,54]$} \\
\hline Makapan Cave & & South Africa & -24.16 & 29.18 & & & & $202,000 *$ & 324,000 * & [55] \\
\hline Mampombo Cave & & Tanzania & & & & & & $31,560^{*}$ & $104,640 *$ & [50] \\
\hline \multirow{4}{*}{ Matupi Cave } & & \multirow{4}{*}{$\begin{array}{l}\text { Democratic } \\
\text { Republic of } \\
\text { Congo }\end{array}$} & \multirow{4}{*}{1.19} & \multirow{4}{*}{30.01} & \multirow{4}{*}{1100} & MAT 23 & & 13,260 * & $14,820^{*}$ & [39] \\
\hline & & & & & & MAT16 & & & "modern" & [39] \\
\hline & & & & & & MAT11 & & $40,100 *$ & & [39] \\
\hline & & & & & & MAT13 & & $990 *$ & 50,330 * & [39] \\
\hline \multirow{2}{*}{ Moomi Cave } & \multirow{2}{*}{138} & \multirow{2}{*}{ Yemen } & \multirow{2}{*}{12.5} & \multirow{2}{*}{54} & \multirow{2}{*}{400} & M1-5 & 293 & 11,086 & 27,370 & [56] \\
\hline & & & & & & M1-2 & & 40,379 & 53,484 & [57] \\
\hline \multirow{3}{*}{ Mukalla Cave } & & \multirow{3}{*}{ Yemen } & \multirow{3}{*}{14.92} & \multirow{3}{*}{48.59} & \multirow{3}{*}{1500} & Y99 & & 119,141 & 358,887 & [58] \\
\hline & & & & & & Y97-4 & & 5630 & 185,600 & [58] \\
\hline & & & & & & Y97-5 & & 8790 & 233,300 & [58] \\
\hline Namaingo Cave & & Tanzania & & & & & & $560^{*}$ & $2640 *$ & [50] \\
\hline
\end{tabular}


Table 1. Cont

\begin{tabular}{|c|c|c|c|c|c|c|c|c|c|c|}
\hline site_name & site_id & Country & $\begin{array}{l}\text { Latitude } \\
\text { (N) }\end{array}$ & $\begin{array}{l}\text { Longitude } \\
\text { (E) }\end{array}$ & $\begin{array}{c}\text { Elevation } \\
\text { (m amsl) }\end{array}$ & entity_name & entity_id & $\begin{array}{l}\text { Min. Year } \\
\text { (BP) }\end{array}$ & $\begin{array}{l}\text { Max. Year } \\
\text { (BP) }\end{array}$ & Reference \\
\hline $\begin{array}{l}\text { Nangoma-Nakitara } \\
\text { Cave }\end{array}$ & & Tanzania & & & & & & $53,560^{*}$ & $77,150^{*}$ & [50] \\
\hline Orumana Cave & & Namibia & -18.26 & 13.89 & 1450 & Orum-1 & & 986 & 47,301 & [32] \\
\hline \multirow{8}{*}{ PP29 } & & \multirow{8}{*}{ South Africa } & \multirow{8}{*}{-34.21} & \multirow{8}{*}{22.09} & \multirow{8}{*}{10} & 46745 & & 67,600 & 112,400 & [59] \\
\hline & & & & & & $46746 a$ & & 82,700 & 99,500 & [59] \\
\hline & & & & & & $46746 \mathrm{~b}$ & & 75,000 & 98,800 & [59] \\
\hline & & & & & & 46747 & & 41,500 & 61,300 & [59] \\
\hline & & & & & & 138862.1 & & 58,500 & 89,200 & [59] \\
\hline & & & & & & $138862.2 a$ & & 102,900 & 109,900 & [59] \\
\hline & & & & & & $138862.2 b$ & & 82,920 & 88,000 & [59] \\
\hline & & & & & & 142828 & & 51,000 & 108,400 & [59] \\
\hline \multirow{3}{*}{ Qunf Cave } & \multirow{3}{*}{159} & \multirow{3}{*}{ Oman } & \multirow{3}{*}{17.17} & \multirow{3}{*}{54.3} & \multirow{3}{*}{650} & Q5 & 351 & 308 & 10,558 & [34] \\
\hline & & & & & & Q5 & & 400 & 10,470 & [60] \\
\hline & & & & & & Q11 & & 3738 & 4929 & [60] \\
\hline \multirow{5}{*}{ Rössing Cave } & & \multirow{5}{*}{ Namibia } & \multirow{5}{*}{-22.53} & \multirow{5}{*}{14.80} & \multirow{5}{*}{332} & & & $26,530 *$ & $480,000 *$ & {$[38,61]$} \\
\hline & & & & & & KOO933 & & $117,000 *$ & $413,000 *$ & {$[61]$} \\
\hline & & & & & & KOO931 & & $363,000^{*}$ & $480,000 *$ & {$[38,61]$} \\
\hline & & & & & & KOO930 & & $89,000^{*}$ & $480,000 *$ & {$[38,61]$} \\
\hline & & & & & & KOO929 & & $369,000 *$ & $439,000 *$ & {$[38,61]$} \\
\hline \multirow{2}{*}{ Rukiessa Cave } & \multirow{2}{*}{22} & \multirow{2}{*}{ Ethiopia } & \multirow{2}{*}{8.60} & \multirow{2}{*}{40.38} & \multirow{2}{*}{1618} & Merc-1 & 87 & -53 & 56 & {$[12,20]$} \\
\hline & & & & & & Asfa-3 & 88 & -53 & 52 & {$[12,20]$} \\
\hline \multirow{7}{*}{ Staircase Cave } & & \multirow{7}{*}{ South Africa } & \multirow{7}{*}{-34.21} & \multirow{7}{*}{22.09} & & 46322 & & 202,400 & 279,100 & [59] \\
\hline & & & & & & $46330 \mathrm{a}$ & & 210,800 & 215,800 & [59] \\
\hline & & & & & & $46330 \mathrm{~b}$ & & 173,500 & 205,700 & [59] \\
\hline & & & & & & 46861 & & 172,000 & 283,200 & [59] \\
\hline & & & & & & 50100 & & 194,500 & 247,800 & [59] \\
\hline & & & & & & 142819 & & 129,900 & 334,700 & [59] \\
\hline & & & & & & 142820 & & 160,900 & 335,600 & [59] \\
\hline Sterkfontein Cave & & South Africa & -26.02 & 27.73 & 1450 & & & $10,000 *$ & $200,000 *$ & [13] \\
\hline \multirow{2}{*}{ Sudwala Cave } & & \multirow{2}{*}{ South Africa } & 2537 & 307 & 975 & SC1 & & 12,790 & 40,220 & [62] \\
\hline & & & $-20.3 \%$ & 30.7 & $9 / 5$ & & & $1160^{*}$ & $403,290 *$ & [62] \\
\hline
\end{tabular}


Table 1. Cont

\begin{tabular}{|c|c|c|c|c|c|c|c|c|c|c|}
\hline site_name & site_id & Country & $\begin{array}{l}\text { Latitude } \\
\text { (N) }\end{array}$ & $\begin{array}{l}\text { Longitude } \\
\text { (E) }\end{array}$ & $\begin{array}{c}\text { Elevation } \\
\text { (m amsl) }\end{array}$ & entity_name & entity_id & $\begin{array}{l}\text { Min. Year } \\
\text { (BP) }\end{array}$ & $\begin{array}{l}\text { Max. Year } \\
\text { (BP) }\end{array}$ & Reference \\
\hline \multirow{2}{*}{ Susah Cave } & & \multirow{2}{*}{ Libya } & \multirow{2}{*}{32.89} & \multirow{2}{*}{21.87} & \multirow{2}{*}{200} & SC-06-01 & & 31,945 & 66,636 & [63] \\
\hline & & & & & & SC-06-01 parallel & & 30,755 & 34,850 & [63] \\
\hline Tinkas Cave & & Namibia & -22.84 & 15.44 & 425 & & & $224,000 *$ & 337,000 * & [38] \\
\hline \multirow{2}{*}{ Wadi Sannur Cave } & & \multirow{2}{*}{ Egypt } & \multirow{2}{*}{28.62} & \multirow{2}{*}{31.28} & \multirow{2}{*}{200} & WSS & & 136,460 & 188,120 & [64] \\
\hline & & & & & & WS-5d & & 127,923 & 365,921 & [65] \\
\hline \multirow{2}{*}{ Wolkberg Cave } & \multirow{2}{*}{172} & \multirow{2}{*}{ South Africa } & \multirow{2}{*}{-24.1} & \multirow{2}{*}{29.88} & \multirow{2}{*}{1450} & W5 & 377 & 39,742 & 57,872 & {$[66]$} \\
\hline & & & & & & & & 1520 * & 29,560 * & [6] \\
\hline Wonderwerk Cave & & South Africa & -27.85 & 23.06 & 1680 & W-1 & & 900 & 34,800 & [67] \\
\hline
\end{tabular}




\section{Key Climate Drivers Across Africa}

To first order, African climate systems are mostly arranged in zonal patterns with variable seasonal rainfall [68-70] (Figure 2). The northern and southern extremes of the continent experience Mediterranean climates with dry summers and winter rains due to the equatorward displacement of the northern and southern hemisphere westerlies. Towards the equator, the Sahara and Namib-Kalahari deserts in the north and south, respectively, are dominated by year-round subtropical anticyclones. Tropical climates between the two desert belts are dominated by the seasonal migration of the Intertropical Convergence Zone (ITCZ) that leads to a bimodal seasonal rainfall distribution in equatorial regions and a single rainfall season in more distal regions. This zonal pattern is regionally modified by atmospheric circulation patterns and topography driving a persistent increase in aridity on the eastern side of the continent. The continental scale structure is further complicated by regional differences, which are summarized below for the regions from which speleothem records are available (Figure 2).

The northwestern part of the Mediterranean climate region of northern Africa (northwest of the Atlas Mountains) receives rainfall from Atlantic Ocean westerly storms that are generally associated with baroclinic activity over the North Atlantic or the North Atlantic Oscillation (NAO) [71]. Semi-arid and arid climates dominate much of northern Africa east of the Atlas Mountains and most cave sites in this region are currently dry with no active speleothem deposition $[63,65]$. Low amounts of winter rainfall along the northern coasts of Africa are usually brought by localized Mediterranean cyclones rather than from the Atlantic Ocean [72]. Winter rainfall in the Sahel is also influenced by the Indian monsoon, via the atmospheric pressure dipole between the western and eastern Mediterranean basins [73]. This results in strong Indian monsoons promoting rainfall in the Sahel and southeastern Mediterranean and suppressing it in the northwestern Mediterranean. Long-term climatic variability across much of northern Africa is dominated by alternation between arid and humid periods, which arise from a combination of intensified winter rainfall and northward migration of the monsoon belt. The latter changes are well known from a range of marine and terrestrial archives and occur during phases of high northern hemisphere summer insolation [72-79].

In eastern Africa, southern Arabia and Madagascar, the meridional passage of the ITCZ over the year controls rainfall seasonality. Monsoonal climates with a single summer wet season occur at higher latitudes of either hemisphere, while double wet seasons occur at lower latitudes where there are two overhead passes of the ITCZ each year [79]. To the east of the Congo Air Boundary, rainfall shares a common moisture source: the western Indian Ocean [80]. Indian Ocean sea surface temperatures (SSTs) play a strong role in modulating modern rainfall amount [81-84] via changes in Walker Circulation. A warming of the western Indian Ocean SSTs and cooling of eastern Indian Ocean weakens the longitudinal SST gradient and leads to stronger westerly winds. This results in a shift in the locus of rainfall towards eastern Africa-a positive Indian Ocean Dipole event [85]. Climate variability on decadal to millennial timescales is dominated by similar but lower frequency "Indian Ocean Dipole-like" modes [86-88]. On orbital timescales, the relationship between Indian Ocean SST and rainfall in eastern Africa switches sign as low glacial SSTs coincide with low sea levels and the exposure of the Sunda and Sahul Shelf which rearranges the Walker circulation to cause an increase of rainfall $[69,79]$.

Located at the southernmost extent of the seasonal ITCZ migration, the subtropical summer rainfall regions of Southern Africa are affected by similar drivers as eastern Africa. Under present day conditions, the positive phase of the Indian Ocean Dipole leads to increased rainfall in the eastern part of this region [89]. In the western parts, in northern Namibia and Botswana, the location of the Congo Air Boundary, a western branch of the ITCZ, determines rainfall amounts and shifts of the moisture source between the tropical Atlantic and western Indian Ocean [90]. Past climate changes in the eastern parts of the southern African summer rainfall region also follow similar patterns as eastern Africa, with Indian Ocean SST being an important driver during interglacials, but the influence of sea level changes taking over on glacial-interglacial timescales [79]. In the western parts of the southern African 
tropics, the tropical rain belt appears to have expanded and contracted between interglacial and glacial phases [88]. The year-round rainfall region on the south coast of Africa gets rainfall from interactions of tropical and temperate atmospheric systems [91]. On glacial-interglacial timescales, the influences of tropical and temperate atmospheric systems across southern Africa were traditionally thought to vary in a straight forward manner with the temperate winter rainfall area expanding and the summer rainfall region becoming more arid during cold phases and vice versa. However, recent studies show that the interactions between tropical and temperate atmospheric systems lead to complex fluctuations of rainfall on various timescales $[59,68]$.

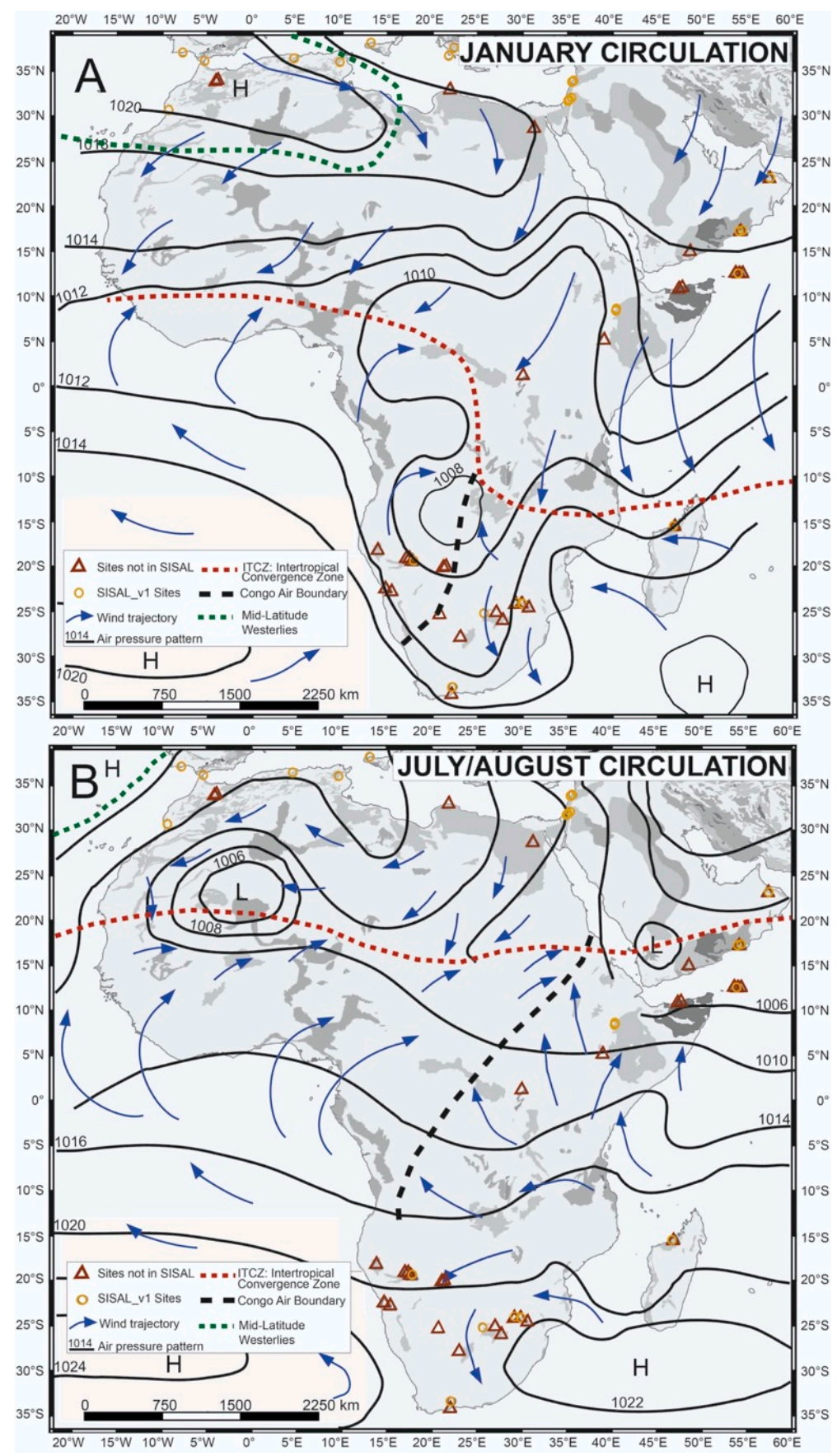

Figure 2. Regional climate and circulation patterns showing the boundaries of the Intertropical Convergence Zone (ICTZ), Congo Air Boundary and Mid-Latitude westerlies (adapted from [80]) and including locations of speleothem records (open circles represent those included in SISAL_v1; triangles represent sites not included in SISAL_v1): (A) January; and (B) July/August. 
The ultimate goal of the SISAL initiative is to look at how climatic systems operated in the past, as indicated by the speleothem records. As many of the karst regions in Africa are located in semi-arid zones, it has been assumed that the growth phases of speleothems at particular sites are indicative of wetter conditions, with hiatuses corresponding to drier conditions $[39,63,65]$. However, there are multiple reasons why stalagmites can stop growing that are unrelated to climate, notably changes in drip hydrology for example due to seismic activity [92]. We argue that the interpretation of single speleothem growth phases as definitive wet/dry indicators should be avoided. Instead, we advocate for a combined approach, where replicating growth phases, corroboration by independent evidence or repeated correlation with climate drivers are used to provide support for the interpretation of speleothem growth phases as indicative of past climates.

\section{Distribution of Speleothem Isotopic Records in Space and Time}

\subsection{Northern Africa: Egypt, Libya, Tunisia, Algeria, Morocco}

Much of northern Africa comprises sediments deposited in the Tethys basin, which have been uplifted during the Alpine-Atlasic Orogeny [93]. Consequently, it is richer in carbonate sediments than most regions of the continent and has strong potential for speleothem-based palaeoclimatology (Figure 1).

In Egypt, one stalactite from Wadi Sannur Cave [64] has provided a record indicating six wet phases between $\sim 188 \mathrm{ka}$ and $136 \mathrm{ka}$ (thousands of years before present, where present is defined as 1950 CE). A stalagmite with double growth axes (WS-5d) from the same cave shows three wet phases at $335 \pm 12 \mathrm{ka}, \sim 219.4 \pm 7.3 \mathrm{ka}$ and $129.1 \pm 1 \mathrm{ka}$, corresponding to Marine Isotope Stage (MIS) 9, 7c and 5e [65], but age reversals do not allow the construction of a reliable age model. The absolute $\delta^{18} \mathrm{O}$ values of the speleothem are $\sim 5 \%$ lower than speleothems considered to reflect a Mediterranean moisture source. Consequently, they have been interpreted as reflecting a long transport distance for atmospheric vapor and suggest the primary driving mechanism is northward migration of the African monsoon system [79]. Although the monsoon rains themselves probably did not reach as far north as Wadi Sannur, wetter conditions there were likely caused by moisture recycling across northern Africa and climate feedbacks from increased vegetation cover [72].

Further west, a single speleothem record from Susah Cave in Libya [63] shows three humid periods during MIS 3 dating to 65-61 ka, 52.5-50.5 ka and 37.5-33 ka. The first and third phases occurred during times when orbital precession caused increased summer insolation in the northern hemisphere. The second growth period represents the first evidence for high obliquity leading to pluvial conditions in the northern African subtropics [72]. Short periods of growth show temporal coherence with Greenland Dansgaard-Oeschger interstadials [72]. Variations of speleothem $\delta^{18} \mathrm{O}$ are in phase with changes of Greenland ice core $\delta^{18} \mathrm{O}$, supporting a distal moisture source from the Atlantic Ocean, likely supplied by winter cyclones [72]. Values of $\delta^{18} \mathrm{O}$ are disconnected from growth rate changes, which suggests that rainfall amount and rainfall source at Susah Cave change independently [72].

Tunisia is equally poorly represented providing one short speleothem record from La Mine Cave that grew between 20 and $5 \mathrm{ka}$ [51]. Oxygen isotopes show a two-step change from the late glacial into the Holocene, which may reflect freshening of the Mediterranean as sea levels rose [94], varying origin of source waters or changes in precipitation amount. Carbon isotopes show a pronounced Bølling-Allerød/Younger Dryas oscillation, with the cool period exhibiting wetter conditions [51]. The stalagmite ceased growth at $5 \mathrm{ka}$, possibly due to insufficient water availability [51].

Algeria has provided only two speleothem records from Gueldaman Cave. These provide a decadal scale isotopic record from $\sim 6.2$ to $\sim 3.3 \mathrm{ka}$ (Figure 3) [44]. The record and its archaeological context show three dry periods from 4.4 to $3.8 \mathrm{ka}[44]$. 

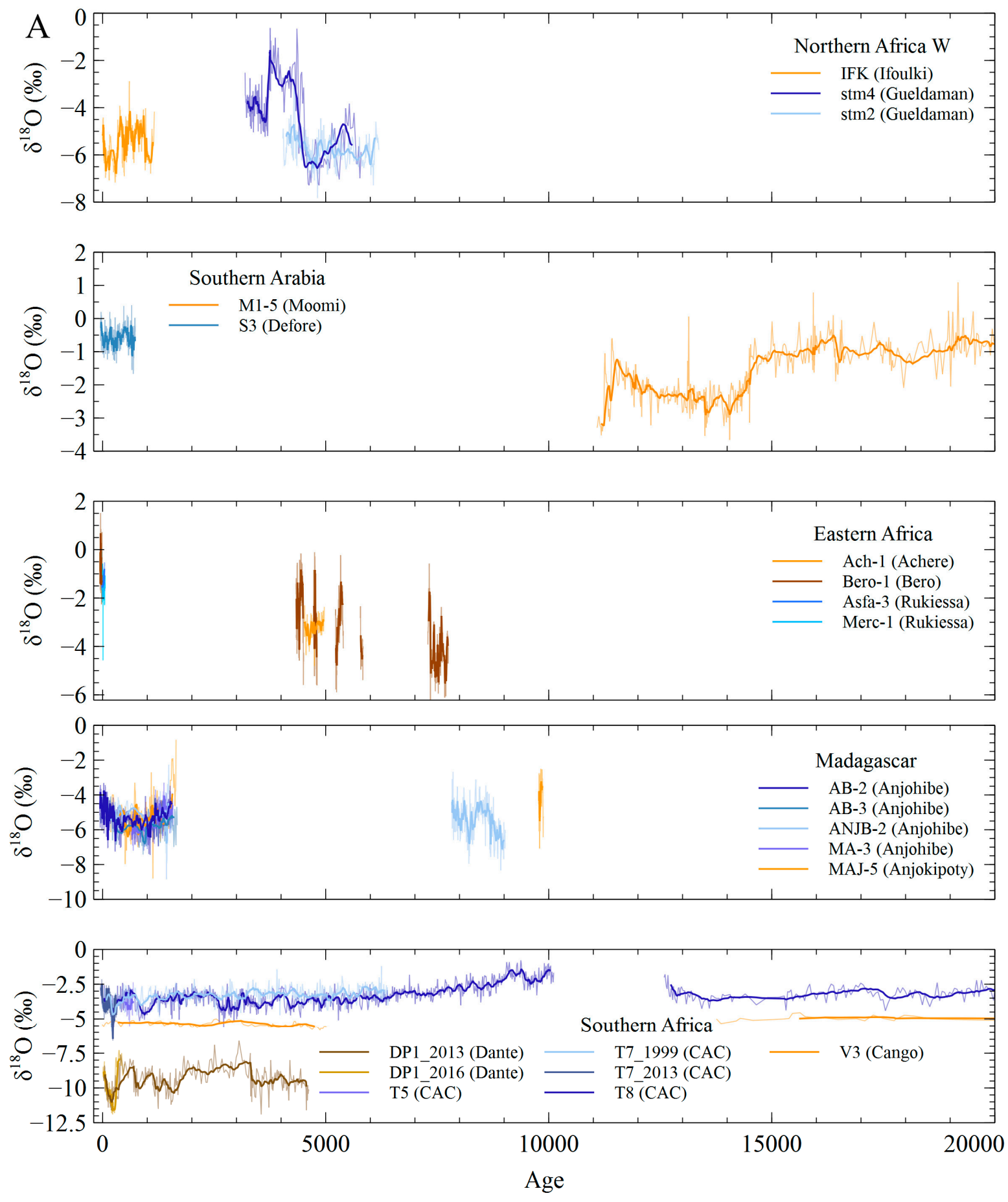

Figure 3. Cont. 

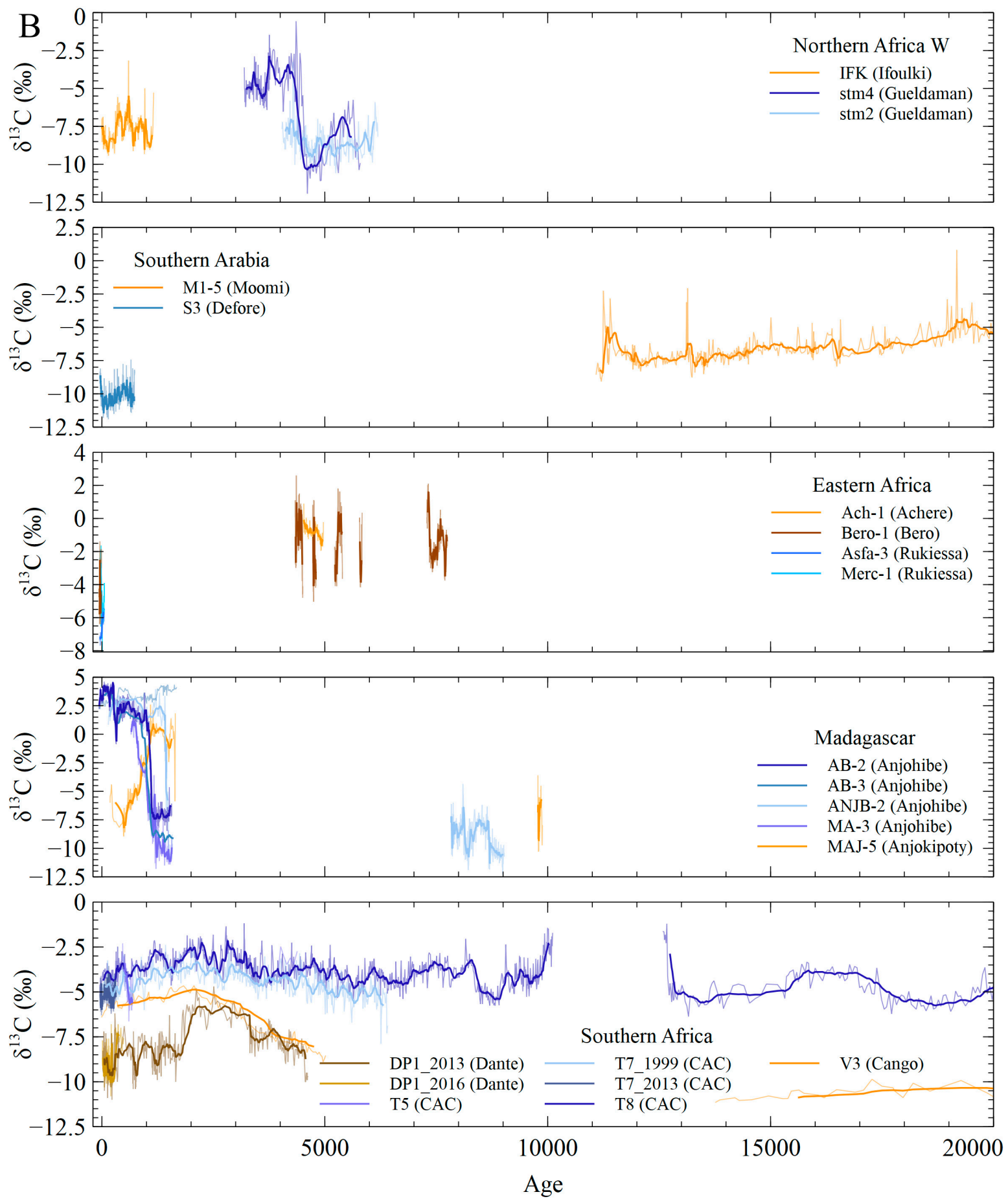

Figure 3. $\delta^{18} \mathrm{O}(\mathbf{A})$; and $\delta^{13} \mathrm{C}(\mathbf{B})$ of speleothem entities included in SISAL_v1 for the last 20,000 years. Subregions identified in Figure 1 are shown in separate sub-plots (none of the sites in northeastern Africa are included in the database). Individual legends are given inside each sub-plot. Cave names are given in the legends after the entity name, CAC, Cold Air Cave.

At least four caves have been extensively investigated in Morocco: Aufous Cave southeast of the Atlas Mountains, Ifoulki Cave, Grotte Prison de Chien and Grotte de Piste to the northwest. Stalagmites from Aufous are beyond the range of U/Th dating and so are at least $500 \mathrm{ka}$ old. Grotte de Piste, Grotte Prison de Chien and Ifoulki Cave have provided multiple stalagmite samples. Two speleothems from Grotte de Piste and Grotte Prison de Chien display prominent oscillations between calcite and aragonite that reflect variations in climate with aragonite more common in drier conditions and calcitic 
speleothems in relatively humid conditions [43]. At Ifoulki Cave, a stalagmite recording the last millennium (790-1953 CE) shows strong wet-dry variability at wavelengths of 15, 62 and 200 years (Figure 3) that were attributed to the NAO [49]. The Medieval Climate Anomaly (MCA, centred on $1120 \mathrm{CE}$ ) was relatively dry, whereas the Little Ice Age (LIA, centred on 1700 CE) was wet [95]. The NAO was also found for a Grotte de Piste speleothem during the mid-Holocene, in which climatic oscillations were anti-correlated with northern European records. A positive correlation with central European records during the early Holocene suggests that changes in northern hemisphere ice volume at the time lead to large scale reorganizations of oceanic and atmospheric circulation systems affecting the structure and "mode" of the NAO [42].

\subsection{Eastern Africa, Arabia and Madagascar}

\subsubsection{Southern Arabian Peninsula}

At the most northerly site in Arabia, Hoti Cave in northern Oman, speleothem growth is largely confined to interglacials: MIS $1,5 \mathrm{e}, 5 \mathrm{a}, 7 \mathrm{a}, 9$ and possibly $11[47,48]$. A positive excursion in $\delta^{18} \mathrm{O}$ indicates the end of the African Humid Period occurred here at $6.1 \mathrm{ka}$ [45]. Marine Isotope Stage 5e had more negative $\delta^{18} \mathrm{O}$ than other interglacials, suggesting it was wetter [46]. Three speleothems from Mukalla Cave in southern Yemen replicate both the growth phase and $\delta^{18} \mathrm{O}$ results from Hoti Cave, with additional growth at $5 \mathrm{c}$ and $7 \mathrm{e}$, indicating that wet interglacials were a feature of the entire southern Arabian Peninsula [58]. Interglacial biased growth suggests that rainfall in Arabia responds more to the $100 \mathrm{kyr}$ glacial/interglacial cycles than to the $23 \mathrm{kyr}$ precession cycle variability observed in upwelling and wind strength in the Arabian Sea [46], with important implications for Out of Africa routes of human migration [58].

Records from Qunf and Defore Caves in southern Oman provide a record of southern Arabian hydroclimate over the Holocene (Figure 3) $[33,60,96]$. There is an abrupt increase in moisture at $9.6 \mathrm{ka}$, almost synchronous with the North Greenland Ice Core Project (NGRIP) ice core record. There is a dry $8.2 \mathrm{ka}$ event and the end of the pluvial period is more gradual, between 6.5 and $4 \mathrm{ka}$, than the abrupt change at Hoti Cave to the north. $\delta^{18} \mathrm{O}$ values during the last $1.5 \mathrm{ka}$ are considerably more enriched (drier conditions) than during the early and mid-Holocene [60]. An annually resolved record of the last 780 years shows significant centennial scale variability that may match variations in solar output [33], as does early Holocene cyclicity at Hoti Cave [45]. During the last millennium, wetter conditions are associated with the MCA and drier conditions with the LIA, consistent with the previously established teleconnections of warm northern hemisphere to a wetter Arabian Peninsula [96]. However, drying conditions in the 20th century occurred despite Indian Ocean warming, suggesting that modern climate change may be producing a different response in Arabian Peninsula hydroclimate to the warmer-wetter response in the paleoclimate record [33].

Further south, rainfall on the Island of Socotra comes in two seasons from the double passage of the ITCZ. The Haggenher mountains act as moisture barriers such that caves in the southwest (Dimarshim) record the southwestern spring rains, while caves in the northeast (Hoq, Casecas and Moomi) record the northeasterly autumn rains. Speleothem $\delta^{18} \mathrm{O}$ records from Moomi Cave show remarkable similarity to the NGRIP ice-core record during MIS 4 [57] and the deglaciation (Figure 3) [56]. Warmer interstadials in Greenland, such as the Dansgaard-Oeschger (D/O) events $[97,98]$ and the Bølling-Allerød, coincide with wetter conditions in northeast Socotra while stadials, such as Heinrich events and the Younger Dryas, coincide with drier conditions. The transitions during the climatic oscillations of the deglaciation are more gradual than the Greenland ice core response, comparable to other northern hemisphere monsoon records around the Indian Ocean.

There is a gradual decline in $\delta^{18} \mathrm{O}$ in the eastern caves of Socotra (Hoq and Casecas Caves) between 6.0 and $3.8 \mathrm{ka}$ [24], consistent with a gradual southerly shift of the ITCZ position over the course of the Holocene in response to changing orbital forcing. During the late Holocene the monsoonal records of Oman and the inter-monsoon records of Socotra are anti-correlated with a gradual wetting 
at Dimarshim Cave over the last $4.4 \mathrm{ka}$ [34]. This was ascribed to changing wind paths to a more oceanic route as the southwest monsoon weakens. Regionally, this result is consistent with a southerly movement of the summer ITCZ over the course of the Holocene: the total amount of precipitation decreases at the northern fringes of the monsoon (Oman) but increases in areas closer to the equator (Socotra) [24,34].

\subsubsection{Mainland Eastern Africa}

Annually laminated stalagmites from the Mechara karst (notably the Achere-Aynage, Bero, Rukiessa and Goda Mea Caves) in Ethiopia have provided short but high-resolution records of the mid-Holocene (Figure 3) [12,20] through to the last interglacial [41]. Recent growth over the twentieth century [99] and cave monitoring [100] provide a basis for interpretation of the records. While the records are interpreted in terms of rainfall amount, the suggested mechanism may be related to degassing and in-cave processes rather than a strict atmospheric control $[12,20]$. The complex double wet season climate of the region, with relatively low variability in precipitation $\delta^{18} \mathrm{O}$ compared to differences arising from mixing within karst aquifers and possible in-cave fractionation effects makes simple wetter/drier climatic interpretations from the oxygen isotope records difficult. Other sources of information, including morphology, fluorescence [12], biomarker analysis [101] and forward $\delta^{18} \mathrm{O}$ modelling [20] have been used to aid paleoclimate interpretations. Forward modelling suggests that decreases in $\delta^{18} \mathrm{O}$ likely reflect increases in summer rains or decreases in spring rains [20].

Together these studies indicate persistent decadal-scale variability in all studied periods in Ethiopia, potentially related to ITCZ movement and western Indian Ocean SSTs. More negative $\delta^{18} \mathrm{O}$ in the early Holocene likely results from long term orbital changes [20]. Mean $\delta^{18} \mathrm{O}$ composition within growth phases from 129 to $108 \mathrm{ka}(-3.82$ to $-7.77 \%)$ were even lower than modern and Holocene stalagmites, indicative of wetter conditions [41].

Twelve speleothems from six caves have been collected from three different areas of the eastern Tanzanian coast [102]. Most of these speleothems were either too porous or had too much detrital Th to produce reliable U-series dates, and even dateable samples had low U content, reducing dating precision [50]. However, the Mafuriko Quarry $\delta^{13} \mathrm{C}$ record shows significant millennial-scale fluctuations between 39 and $27 \mathrm{ka}$. Although the age model prevents 1:1 association, the record appears to show wetter conditions during Dansgaard-Oeschger events 6-8.

\subsubsection{Madagascar}

Speleothems from two caves in the northwest of Madagascar (Anjohibe, Anjokipoty) provide insight into southern hemisphere monsoon dynamics. The first records from the region showed Walker circulation influences on hydroclimate over the past 500 years, with stalagmite layer width correlating with the Southern-Oscillation Index [18]. Scroxton et al. (2017) [15] produced a high-resolution isotope record covering the last 1700 years showing in-phase coherence at the multi-decadal scale with the Oman speleothem record [33] and with lake-based hydroclimate reconstructions across eastern Africa at the multi-centennial scale [103-105]. These results suggest that sea surface temperature may be the dominant driver of regional hydroclimate variability at these timescales. Burns et al. (2016) [14] identified a rapid landscape transformation around $900 \mathrm{CE}$, recognized by a large $\delta^{13} \mathrm{C}$ shift, with no $\delta^{18} \mathrm{O}$ change (Figure 3). The change, replicated by Voarintsoa et al., [16] (Figure 3) and consistent with regional lake core records $[106,107]$, was attributed to a switch from $C_{3}$ to $C_{4}$ flora and associated with the arrival of slash and burn agriculture. Early Holocene speleothems from Anjohibe and Anjokipoty indicate wetter conditions, including a wet 8.2 ka event [17]. 


\subsection{Southern Africa}

\subsubsection{The Summer Rainfall Region}

Many of the caves in the summer rainfall region are formed in dolomite which leads to a higher concentration of magnesium in drip waters and deposition of aragonite speleothems [108]. This affects the isotopic composition and trace element concentrations, including uranium, both at initial deposition and where aragonite recrystallizes into secondary calcite $[109,110]$. Monitoring of the mineralogy and testing for recrystallization are therefore crucial in these caves to assess the value of a sample for paleoenvironmental studies.

$\delta^{13} \mathrm{C}$ values of speleothems from the South African summer rainfall region are traditionally interpreted to reflect shifts of the relative abundance of $C_{3}$ and $C_{4}$ plants in the vegetation above the cave, as both types of vegetation are common in the region $[6,29]$. Although vegetation changes may also affect $\delta^{13} \mathrm{C}$ in northern Namibia/Botswana, other lines of evidence (including $\delta^{18} \mathrm{O}$, mineralogy, petrography, type of layering and thickness of lamina) suggest that higher $\delta^{13} \mathrm{C}$ values are generally associated with drier conditions and lower values with wetter periods, making prior calcite precipitation (PCP) a more likely driver [31,32].

The oldest analysed speleothems in the southern African summer rainfall region originate from Collapsed Cone at Makapansgat Limeworks and from Buffalo Cave; they indicate the spread of $\mathrm{C}_{4}$ grasses across southern Africa between the end of the Neogene and the early Pleistocene [10,11]. While the initial spread of $\mathrm{C}_{4}$ grasses was probably caused by falling levels of atmospheric $p \mathrm{CO}_{2}$, a subsequent expansion of $\mathrm{C}_{4}$ grasses in the summer rainfall region at $\sim 1.7$ Ma was caused by drying climates due to the reorganization of tropical circulation $[10,11]$. Changes in the net water budget, indicated by $\delta^{18} \mathrm{O}$ and lamina thickness, follow a precessional periodicity at this time $[13,111]$.

The last glacial cycle is well represented in speleothem records from this region starting with a phase of deposition at Wolkberg Cave (58-46 ka) [66], Gladysvale Cave (56-42 ka) [40] and Lobatse Cave $(51-43 \mathrm{ka})[52,53]$. Speleothem growth phases and stable isotopic records from Wolkberg Cave and Lobatse Cave support a wet and warm climate with a trend towards drier and cooler conditions from 50 to $45 \mathrm{ka}[52,53,66]$. Speleothem deposition at Orumana Cave in northwestern Namibia starts around $47.5 \mathrm{ka}$ and lasted at least until $24 \mathrm{ka}$ [32] suggesting more consistently wet conditions here than in the northern part of South Africa. A short second phase of speleothem formation at $40 \mathrm{ka}$ in Wolkberg Cave overlaps with the onset of deposition in Sudwala Cave $(40 \mathrm{ka})[62,66]$ and renewed speleothem formation at Lobatse Cave ( $\sim 38 \mathrm{ka})$ [53]. The period between 35 and 30 ka saw cessation of speleothem deposition in Wonderwerk Cave (33 ka), Echo Cave (30 ka), Sudwala Cave (35 ka), Lobatse Cave (35 ka) and Sterkfontein Caves (after $30 \mathrm{ka}$ ) [13,53]. Evidence of cave flooding at Echo Cave (30 ka) and geochemical evidence and detrital material at Sudwala Cave (35 ka) suggest that wetter conditions are a more likely explanation for the cessation of speleothem formation than aridification [28,53].

Speleothem deposition resumes at Lobatse Cave at $27 \mathrm{ka}$ with generally cooler conditions than in its first phase of deposition (51-43 ka) and a higher abundance of $C_{4}$ grasses [28,52] or drier conditions if $\delta^{13} \mathrm{C}$ is interpreted in terms of PCP. Speleothem formation starts at Cold Air Cave and Wonderwerk Cave at $\sim 24$ ka with stable isotopes from Wonderwerk indicative of warm and dry conditions $[29,67]$. Records from Orumana Cave in Namibia also suggest drier conditions there between 20 and $14.5 \mathrm{ka}$ than between $\sim 47-39 \mathrm{ka}$ [32]. Continued aridification in northern Namibia during the early part of the Antarctic Cold Reversal (ACR) is associated with a hiatus at Orumana Cave at $14.5 \mathrm{ka}$ [32]. A short deposition phase at Drotsky's Cave at $14.5 \mathrm{ka}$ is followed by a hiatus [39]. Cold and dry conditions are also indicated for the ACR (14.7-13.0 ka) in Cold Air Cave (Figure 3) and Sudwala Cave [62].

The onset of the Younger Dryas $(\sim 12.9-11.7 \mathrm{ka})$ is associated with cessation of speleothem deposition (Sudwala: 12.8 ka; Wonderwerk: 13 ka; Cold Air Cave: 12.7 ka) [29,62,67]. The Early Holocene is covered by only one speleothem from Cold Air Cave which suggests warm but dry conditions between 10 and 6 ka [29]. A speleothem from Dante Cave in northeastern Namibia covers the past $4.7 \mathrm{ka}$ (Figure 3) [31]. A short-wet period around $3.3 \mathrm{ka}$ ago at Dante Cave is followed by very 
dry conditions until $1.8 \mathrm{ka}$, when an abrupt transition to wetter conditions overlaps with the migration of Iron Age herders from northern Africa into southern Africa [31,112]. Wet conditions are also evident in records from Cold Air Cave between 1.2 and $0.6 \mathrm{ka}$ (Figure 3) [29,113]. The LIA $(\sim 0.7-0.1 \mathrm{ka})$ was cool and dry at Cold Air Cave with the coldest interval centred between 1690 and 1740 CE following the Maunder Minimum [29,113,114]. In northern Namibia, however, records from Orumana and Dante Cave suggest very wet conditions especially during the Maunder (305-235 years BP; 1645-1715 CE) and Dalton (160-120 years BP; 1790-1830 CE) minima in solar activity [32,115].

\subsubsection{Year-Round Rainfall Region}

The narrow strip along the southern coast of Africa sits at the intersection between the subtropical summer rainfall region and the Mediterranean winter rainfall region and receives rainfall all year round; this region is represented by four cave sites. A stalagmite from Cango Cave covers the last $\sim 47 \mathrm{ka}$ with a hiatus between $\sim 17$ and $6 \mathrm{ka}$ (Figure 3) [5]. However, there is a discrepancy between the radiocarbon and U-series dates on this speleothem $[5,23]$ and an update of the age model is recommended. Values of $\delta^{13} \mathrm{C}$ at Cango Cave were interpreted to reflect shifts of the proportion of $\mathrm{C}_{3}$ and $\mathrm{C}_{4}$ plants in the vegetation above the cave; $\delta^{18} \mathrm{O}$ values only vary by $\sim 1.5 \%$ with no marked shift between the last glacial and the Holocene [5].

Two studies of speleothem records at Pinnacle Point on the south coast of South Africa, show considerably larger variability of $\delta^{18} \mathrm{O}$ than at Cango Cave albeit during different time intervals. This is likely due to the difference in sampling resolution between these records. A first record from Crevice Cave covering the interval between 90 and $53 \mathrm{ka}$ [30] was extended by adding speleothem samples from PP29 (112-43 ka) and Staircase Cave (330-130 ka) [59]. The caves at Pinnacle Point are not classical karst caves hosted in dolomite or limestone, but instead formed in crevices in the local Cape Supergroup sandstones. However, a combination of repetition tests and Hendy tests at the three caves supports environmental factors as being the main drivers of isotopic change $[30,59]$. Variations of $\delta^{13} \mathrm{C}$ were interpreted as reflecting changes of vegetation above the caves. Monitoring of rainwater $\delta^{18} \mathrm{O}$ in the nearby town of Mossel Bay has shown considerable seasonal variations [30,116]. Changes of the $\delta^{18} \mathrm{O}$ values of speleothems therefore have been interpreted in terms of variations in the seasonality of rainfall and associated synoptic conditions [30,59]. Higher summer rainfall and increased abundance of $\mathrm{C}_{4}$ plants are usually associated with higher summer insolation in the southern hemisphere during phases of increased precession parameter. Winter rainfall and $C_{3}$ vegetation are more common in phases with low precession parameters or during interglacial phases when the westerlies are shifted south.

\section{New Insights from the SISAL_v1 Database}

\subsection{Regional Speleothem Age Distributions}

When supported by multiple speleothems from multiple caves and/or other paleoclimate proxies such as lake sediment cores, variability in speleothem age distribution (Figure 4) can be used as a proxy for growth phases and interpreted as a first order estimate of wetter vs. drier conditions promoting/inhibiting speleothem growth, in both semi-arid and tropical environments [115,117]. Although secondary effects such as reduced evapotranspiration during colder conditions can influence certain regions.

Speleothem deposition in the northern African region appears uneven due to irregular sampling of multiple caves in multiple climatic regions. At caves in northwestern Africa (Tunisia, Algeria and Morocco). speleothem deposition has mainly been documented during the Holocene with few ages in the late Pleistocene [42]. Deposition in this region is driven by the temperate westerlies. On glacial-interglacial timescales changes in the volume of ice and the effects of meltwater on oceanic circulation in the north Atlantic can cause major reorganizations of these atmospheric systems which leads to changing relationships between rainfall in northwestern Africa with other regions around 
the Mediterranean Sea and in Europe [42,44,51]. These Atlantic-forced changes are also recorded in the scarce lake sediment records in northwestern Africa through the Holocene with both long-term (African Humid Period-Late Holocene transition) and multi-centennial variabilities recorded in records from Lake Sidi Ali in Morocco [118].
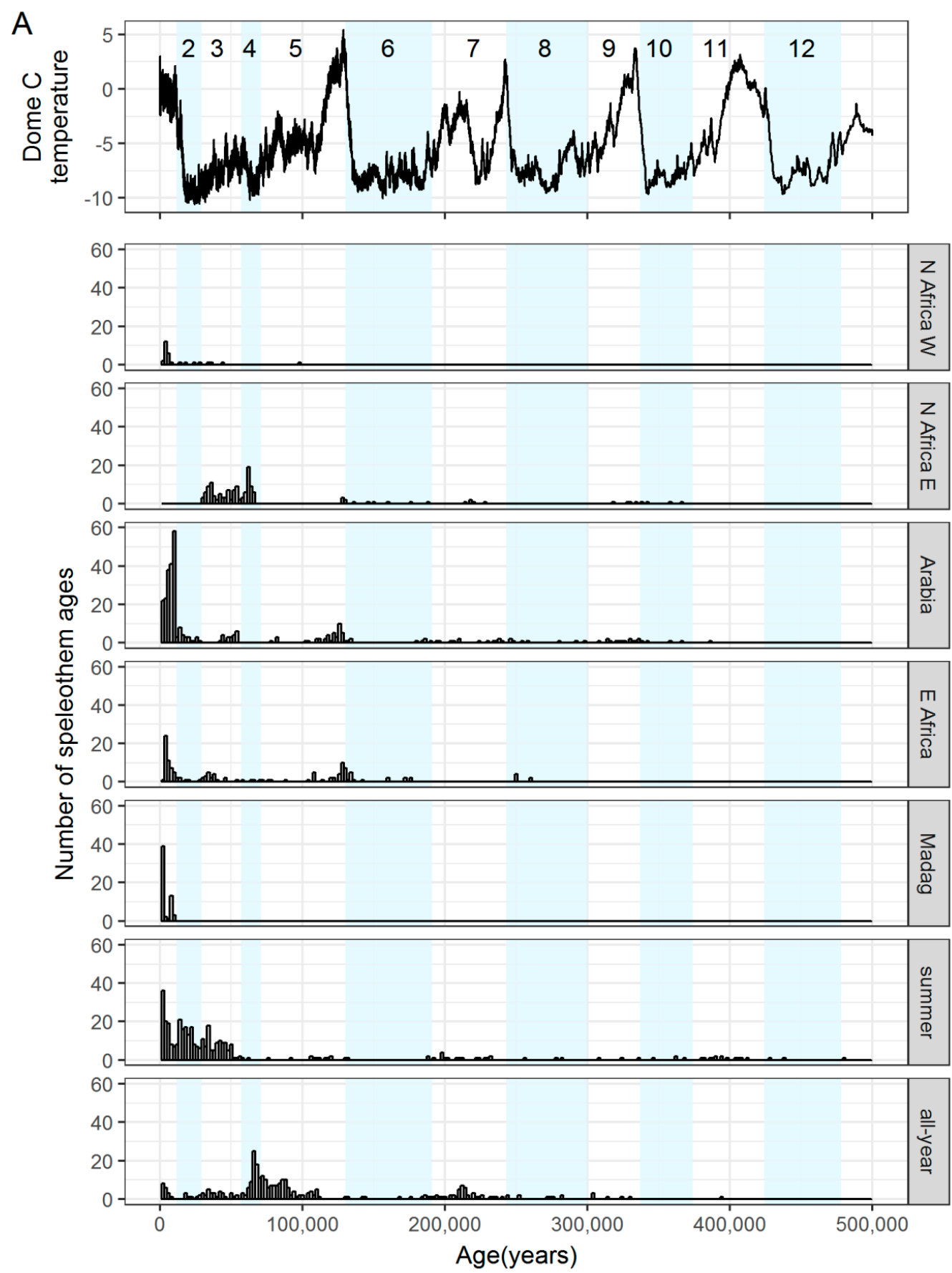

Figure 4. Cont. 

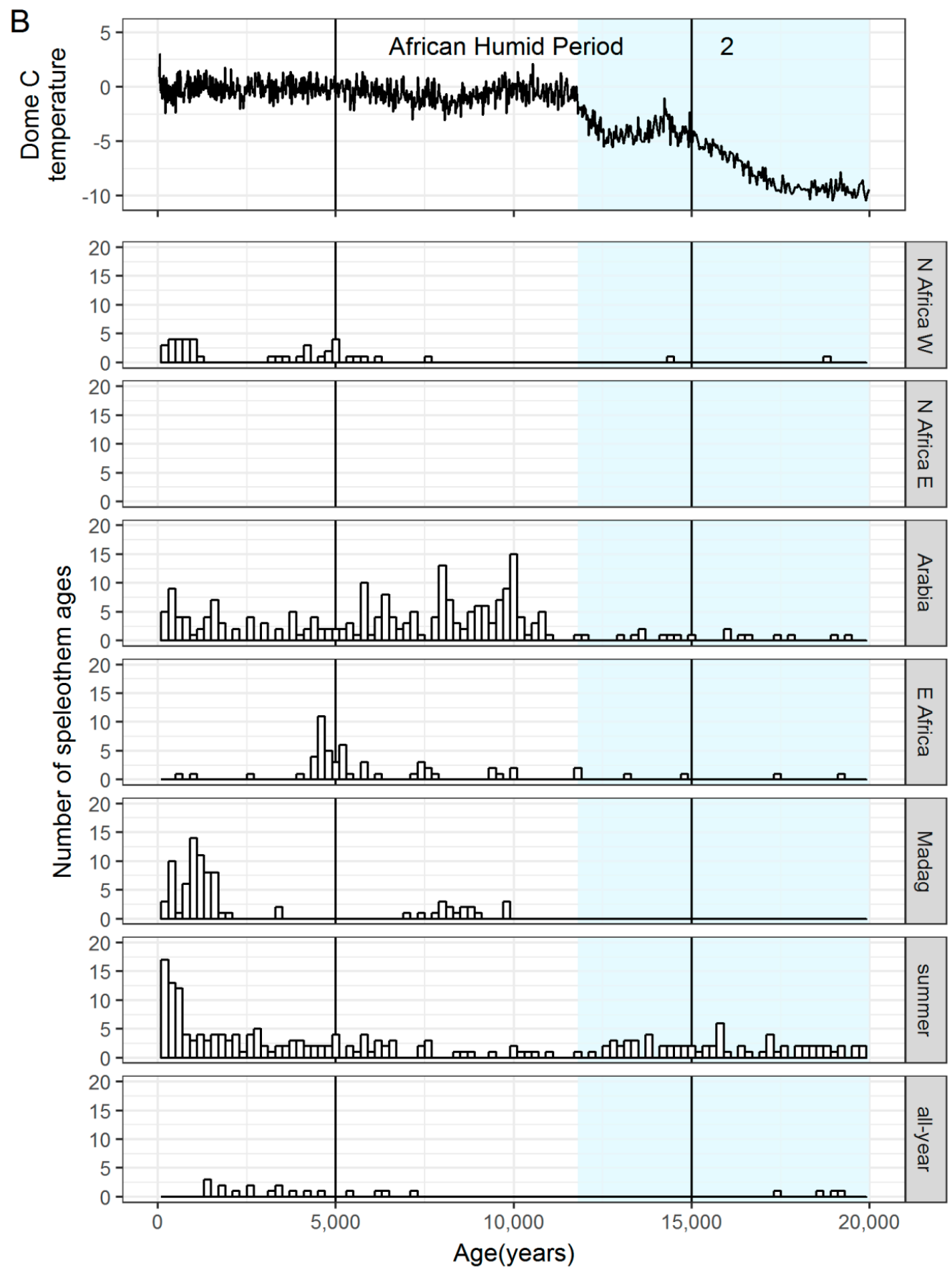

Figure 4. Age distribution histograms of ages measured on speleothems separated by regions indicated in Figure 1 (Southern African summer and year-round rainfall regions are abbreviated as "summer" and "all-year", respectively): (A) for the last $500 \mathrm{ka}$; and (B) for the last $20 \mathrm{ka}$. In both panels: temperature reconstructions (relative to present day) from EPICA Dome C ice core in Antarctica [119]. Light blue shading marks glacial intervals. Numbers at the top of (A) indicate MIS intervals. Vertical lines in (A) mark the boundaries of the African Humid Period.

In northeastern Africa, speleothem deposition is associated with large scale northern African pluvials that lead to the formation of lakes in the now hyperarid interior [63,65]. The largest of these are the "Mega-Lakes" positioned in southern Tunisia/Algeria [120], Chad and surrounding countries (Chad) [121], northeast Sudan (Darfur) [122], southwest Libya (Fezzan) [75] and Algeria (Ahnet-Mouydir) [123]. With the exception of Lake Chad, the status of these deposits as continuous 
lakes as opposed to discontinuous wetlands remains debated [124], and the chronology of Lakes Darfur, Ahnet-Mouydir and Chotts remains problematic. However, it is clear that during the early Holocene, parts of MIS 5 and earlier times in the Quaternary Lake Chad has been very large (up to $350,000 \mathrm{~km}^{2}$ ) and there has been increased surface water in the Fezzan basin. Wet conditions in the Fezzan basin during the early Holocene are suggested by surface water in Lake Shati, [125], evidence of vegetation in the region and multiple carbonate-forming springs [126]. There are also OSL-based dates of similar deposits of various ages in Fezzan within MIS 5 [75]. Early Holocene and MIS 5 carbonate-forming spring deposits are also reported from northwestern Egypt $[76,127]$. Understanding the pluvial periods implied by these deposits is complicated by their discontinuous nature, uncertain timing and debates over the relative change in rainfall they represent [124]. However, these deposits are consistent with the concept of regional rainfall changes forced by increased summer insolation in the northern hemisphere. Under this model, northern summer heating causes a northward shift of ITCZ rainfall during phases when the boreal summer solstice is close to perihelion (low precession index) [128]. At these times, enhanced freshwater runoff from northern Africa leads to stratification of the water column in the Eastern Mediterranean Basin and the deposition of sapropel layers [72]. Indeed, these "Mediterranean Precession-Related Sapropels" are known at least since the Miocene [129]. Deposition phases in Egypt with ages of 340 to $317 \mathrm{ka}, 219-214 \mathrm{ka}$ and 130-128 ka overlap with such extreme pluvials (sapropels 10, 8 and 5) [79]. The lack of coverage of younger sapropels might be due to the low number of studies and speleothem samples from the region. The Susah Cave record in Libya presents rare evidence of increased effective rainfall in northern African during parts of the last glacial period. Major deposition periods are out of phase with the monsoonal rainfall registered in Egyptian speleothems and sapropels and minor depositional phases commonly overlap with Greenland warm phases suggesting important influences of Atlantic moisture in this region [72]. One wet phase identified in Libya has been associated with high obliquity leading to a similar outcome [72]. Dry periods observed in Gueldaman Cave (Algeria) [44] were also identified in La Mine Cave (Tunisia) [51] and other sites surrounding the Mediterranean [130-133]. These observations indicate that perturbations of the westerlies triggered from high latitudes affected the regional climatic regime across the Mediterranean Basin during the Mid-Holocene. This interpretation is highly compatible with a similarly high-resolution lake geochemistry and palynology record from Lake Sidi Ali in Morocco [118].

Speleothem deposition in southern Arabia is mostly centred on interglacial phases and northern hemisphere warm intervals within the Holocene (Figure 4) $[34,47,58,96,134]$. The area represents the northernmost extent of the migrations of the ITCZ rainfall belt and the Indian Summer Monsoon [47]. Most of the intervals of deposition in Arabia overlap with deposition in northeastern Africa, but the phases of deposition are longer in Arabia than northeastern Africa. This difference could reflect the more southern position of the Arabian sites where a more frequent or extended influence of the tropical rain belt is likely, or the orographic nature of southern Arabian rainfall. There might also be a difference in the timing of wet periods of the Indian Monsoon System and African pluvial periods. The highest number of speleothems in southern Arabia date to the early Holocene covering the younger half of the African Humid Period between $\sim 10$ and $5 \mathrm{ka}$ (Figure 4). Evidence from eastern African lakes suggest that this interval was generally more humid than the present-day in locations north of $10^{\circ} \mathrm{S}$, including Lakes Victoria, Tanganyika, Sugutawas, Turkana, Challa, Chad and Tana [135-140]. Wet conditions also extended across large parts of northern Africa as supported by sapropel deposition in the Eastern Mediterranean [72].

The few dates on speleothems in eastern Africa suggest conditions in both glacial and interglacial intervals were humid enough for speleothem growth as expected from a more equatorial location. Therefore, instead of growth phases, the substantial isotopic variability in these speleothems are a better indicator of wetter and drier periods [41]. The limited sampling in Madagascar has, so far, mostly produced samples dating to the last $2 \mathrm{ka}$. The small number of early Holocene samples does not allow for a definitive statement about the depositional phases but is consistent with a northern position of the ITCZ during the African Humid Period (Figure 4). 
Speleothem deposition in the southern African summer rainfall region is more common in interglacial phases than in glacials, up until the last glacial phase (Figure 4). Depositional intervals thus generally overlap with those in southern Arabia (Figure 4). The coherence of depositional phases of speleothems from the northern (southern Arabia) and southern (southern African summer rainfall) extremes of the influence of ITCZ migrations supports a generally larger latitudinal range of these migrations during interglacials or a widening of the rainfall belt itself $[79,141]$. During glacials, increased polar ice volume and a contraction of tropical circulation systems between equatorward shifted westerlies in both hemispheres may have caused drier climates in these regions. The last glacial phase does however show considerable speleothem formation in the southern African summer rainfall zone (Figure 4). Most of the eastern African lake records suggest dry conditions during much of the last glacial phase $[137,138,142]$ and also proxy records from Tswaing Crater (Pretoria Saltpan) in South Africa and Lake Tritrivakley in Madagascar support dry conditions [143-145]. Only Lakes Malawi and Masoko in the southern part of eastern Africa show some evidence of wetter conditions during the last glacial [145-148]. While the wet conditions in some of these lakes might support a southward shift of the ITCZ due to the disproportionate cooling of the larger landmass in the northern hemisphere during cold phases [149], the complex geographical pattern of wet and dry conditions do not support widespread rainfall in the southern African summer rainfall area at the time. The observed peak of speleothem deposition in the last glacial could (Figure 4) also be explained with increased effective precipitation and water infiltration as the lower temperatures reduce evaporation [40]. The number of speleothems forming in the early Holocene in this region is low compared to the last glacial phase and the mid-late Holocene, supporting dry conditions and a northern position of the ITCZ during much of the African Humid Period (Figure 4).

In the year-round rainfall region of southern Africa, much of the rainfall is associated with connections between tropical and temperate rainfall systems [150]. Speleothem deposition is more common in interglacials, mainly in MIS 5 and 7 (Figure 4A). This may represent the widening of the seasonal latitudinal migration of the ITCZ during interglacials allowing for good connectivity between tropical and temperate low-pressure systems [91]. The largest number of speleothem ages in the year-round rainfall region was, however, measured in early MIS 4 (Figure 4A). A high precession parameter during this time suggests a possible southward shift of the ITCZ. At the same time, the westerlies were strengthened [151] which allowed for good connectivity of tropical and temperate rainfall systems [91]. One sample with last glacial to Holocene age was reported from the year-round rainfall region of southern Africa. This sample shows a hiatus in deposition between 16 and $8 \mathrm{ka}$ [5], supporting the dry conditions suggested in the southern African speleothem records (Figure 4) and a northward shift of the ITCZ during the African Humid Period.

\subsection{Pan African Ranges of $\delta^{18} \mathrm{O}$ and $\delta^{13} \mathrm{C}$}

Recent and historical speleothem stable isotopes in Africa reflect the modern isoscapes to the first order (Figure 5). This suggests that speleothem $\delta^{18} \mathrm{O}$ is a good recorder of precipitation $\delta^{18} \mathrm{O}$, albeit likely with some "in-karst" modification. The most enriched values $(-0.3 \%$ to $-1.3 \%)$ are found in southern Arabia and eastern Africa, intermediate values in Madagascar, Morocco and South Africa $(-4 \%$ to $-7 \%$ ) and the most depleted in southwestern Africa ( $-8 \%$ to $-10 \%)$. While isotopic modification of the $\delta^{13} \mathrm{C}$ signature from plant matter to dissolved inorganic carbon to speleothem calcite is more complex, the distribution of modern speleothem $\delta^{13} \mathrm{C}$ values replicates the division between $C_{3}$ and $C_{4}$ vegetation on the continent. Here, $C_{4}$ vegetation corresponds to speleothem $\delta^{13} \mathrm{C}$ greater than $-6 \%$ [152] in Madagascar and southeastern Africa and $C_{3}$ vegetation with speleothem $\delta^{13} \mathrm{C}$ less than $-6 \%$ in Morocco and southern South Africa. The mixed signal in eastern Africa may reflect the proximity of cave sites to the $C_{3} / C_{4}$ ecotone and therefore the effects of local rather than regional vegetation. There is a discrepancy between the Dante Cave record [31] (suggesting $C_{3}$ ) and the isoscape (likely $\mathrm{C}_{4}$ ). This might represent highly localised vegetation, in-cave fractionation, or rapid land use change by humans since the stalagmites stopped growing in the mid 20th Century. 

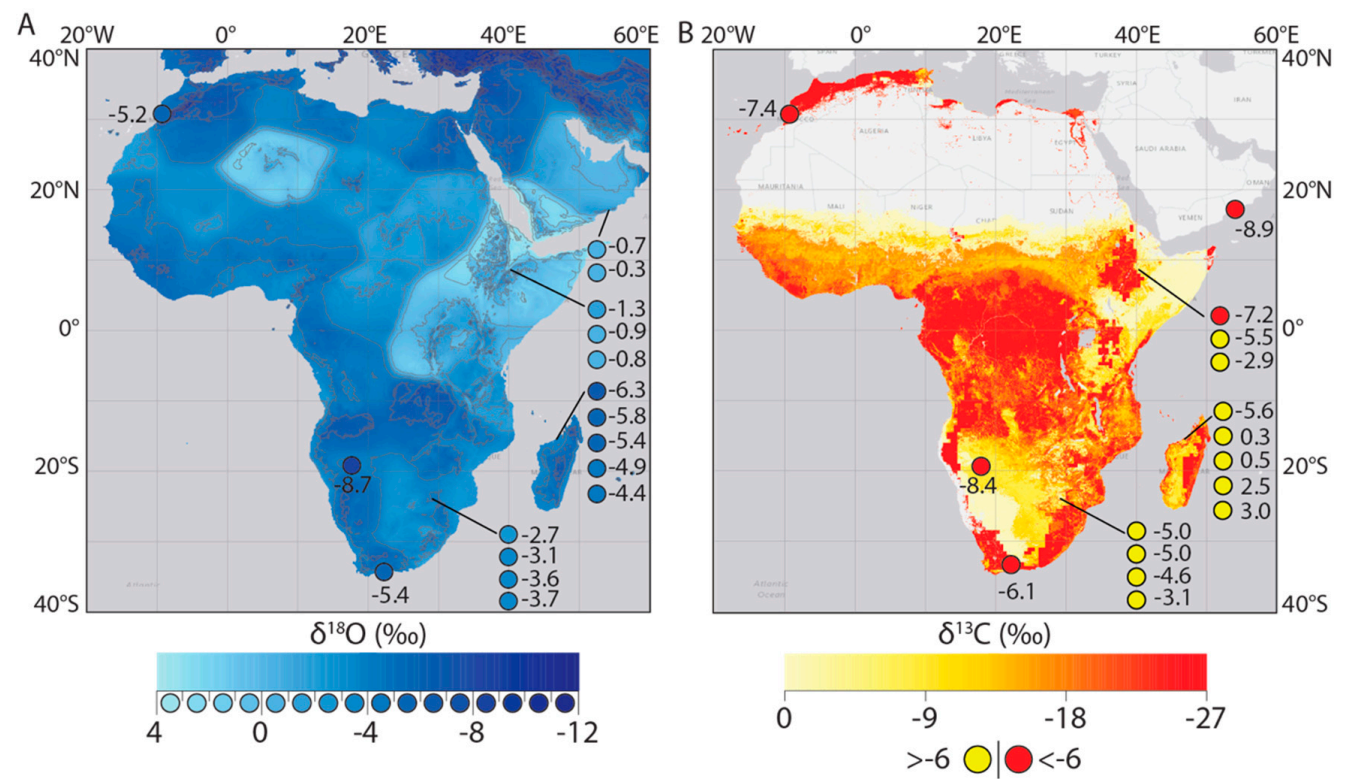

Figure 5. Modern isoscapes and recent speleothem stable isotope values: (A) speleothem $\delta^{18} \mathrm{O}$ (circles) on interpolated map of Global Network of Isotopes in Precipitation mean annual $\delta^{18} \mathrm{O}[153,154]$; and (B) speleothem $\delta^{13} \mathrm{C}$ (circles) on modelled plant $\delta^{13} \mathrm{C}$ [155] based on MODIS data [152]. $\delta^{13} \mathrm{C}$ map colours are blank in Africa where there is little or no vegetation and outside of Africa where the model was not run. Speleothem stable isotopes are the mean of the most recent five measurements for each stalagmite growing at any point during the last 2000 years. Speleothem colours are on an identical scale as the modern isoscape for $\delta^{18} \mathrm{O}$, but divided either side of $-6 \%$ for $\delta^{13} \mathrm{C}$ (based on [156]), as there is substantial fractionation between leaf cover and speleothem calcite, and it has not yet been established how speleothem $\delta^{13} \mathrm{C}$ responds to mixed $C_{3} / C_{4}$ vegetation above the cave $[156,157]$.

In the paleoclimate record, African speleothem $\delta^{18} \mathrm{O}$ mostly ranges from +1 to $-9 \%$ except for Dante Cave in northwestern Namibia where isotopic values reach lower than $-10 \%$, possibly because of the inland location of the site. In northern Africa, the Holocene records from Iflouki, La Mine and Gueldaman Caves show $\delta^{18} \mathrm{O}$ signatures close to present Mediterranean precipitation $\delta^{18} \mathrm{O}$ [158]. The large variability of $\delta^{18} \mathrm{O}$ values at Gueldaman Cave indicates variable moisture conditions including prominent dry periods during the late-Holocene. The Arabian records (Hoti, Qunf, Defore and Moomi Caves) show generally slightly more enriched $\delta^{18} \mathrm{O}$ values than the northern African records. We also find more isotopic enrichment at Defore Cave compared to Hoti, Moomi and Qunf Caves. This offset confirms that the Arabian and Mediterranean sites are not within the same precipitation system and reflects the short transport distance between Arabian sites and the Indian Ocean. From Arabia southwards to eastern Africa, $\delta^{18} \mathrm{O}$ becomes more depleted (Figure 6A). This spatial pattern may reflect the amount effect commonly observed in monsoonal rainfall [159]. Even during phases when the ITCZ is in a northern position rainfall amounts are lower at the fringes of the monsoon influence (southern Arabia) than in its centre (equatorial eastern Africa), which would lead to the overall higher $\delta^{18} \mathrm{O}$ values observed in southern Arabia (Figure 6A). The inverse pattern is however not observed in sites to the south of the equator, with southern African sites (Cold Air Cave, Wolkberg Cave, Buffalo Cave, Lobatse Cave and Cango Cave) all recording $\delta^{18} \mathrm{O}$ values of around $-5 \%$. While this may well be due to sampling bias, it also hints at mechanisms other than the position of the ITCZ and the amount effect driving the $\delta^{18} \mathrm{O}$ values.

The $\delta^{13} \mathrm{C}$ values of African speleothems range from $\sim 3 \%$ to $-10 \%$ (Figure $6 \mathrm{~B}$ ). $\delta^{13} \mathrm{C}$ values in northern African records range mainly between $-10 \%$ and $-5 \%$ and reflect higher abundance of $\mathrm{C}_{4}$ grasses and/or stronger PCP associated with cool/dry conditions $[44,49,51]$. Speleothem records from southern Arabia and eastern Africa show a trend towards more positive values closer to the equator (Figure $6 \mathrm{~B}$ ). In southern Africa, $\delta^{13} \mathrm{C}$ values at Dante Cave are comparatively low ( -5 to 
$-10 \%$ ) [31,62], which also may reflect the inland location of the site. The South African sites (Cold Air Cave, Wolkberg Cave, Buffalo Cave, Lobatse Cave and Cango Cave), to some extent, show a similar trend as the southern Arabian and eastern African sites with decreasing values with increasing distance from the equator (Figure 6B). This tendency in the data is unexpected, because higher temperature and rainfall in the tropics should lead to lower speleothem $\delta^{13} C$ [51]. This inversion of the expected trend may arise from differences in gas exchange within the cave, which is considered important in Ethiopia [20].
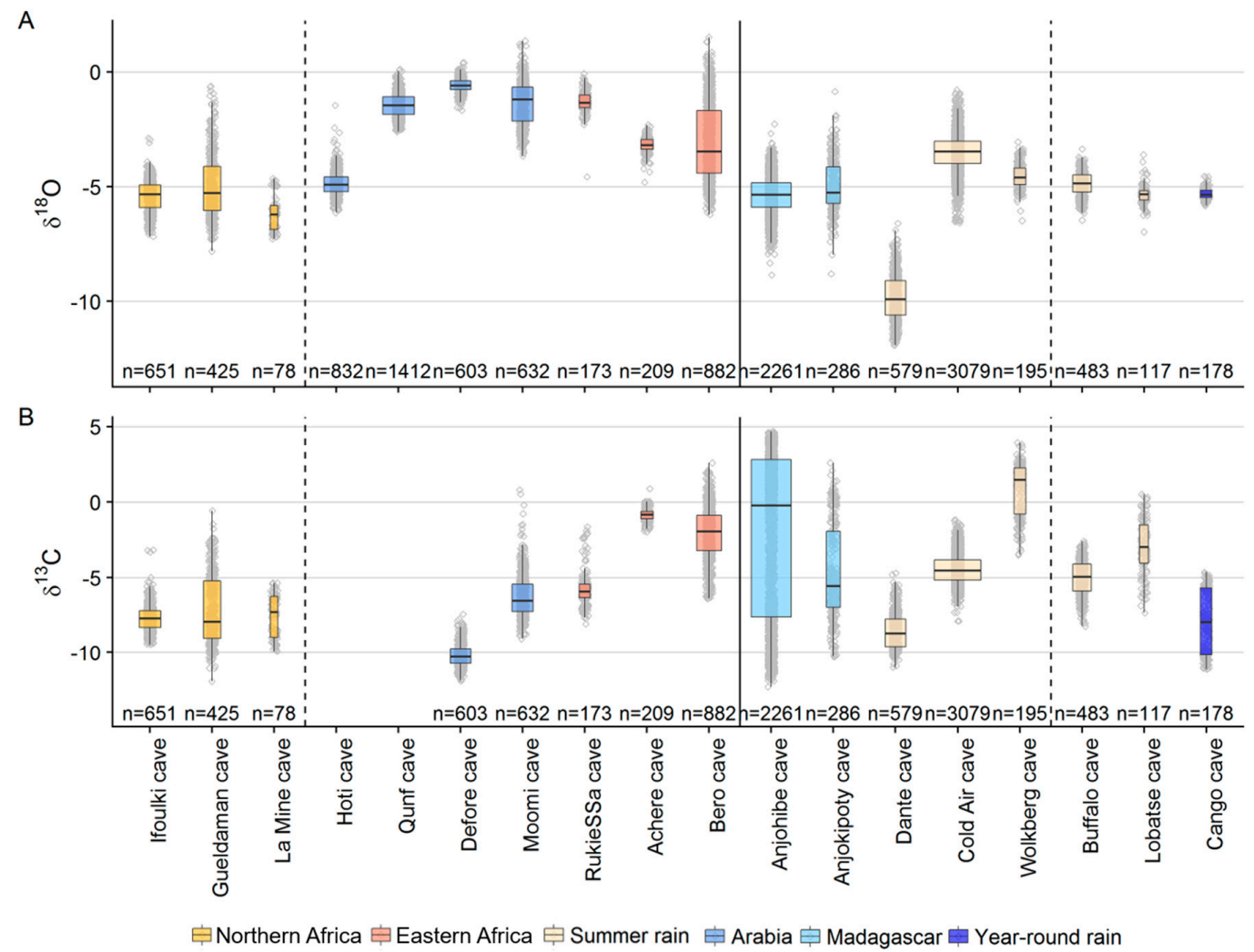

Figure 6. The range of isotope values for each cave in SISAL_v1: (A) $\delta^{18} \mathrm{O}$; and (B) $\delta^{13} \mathrm{C}$. Sites are arranged by region as indicated in Figure 1 from north to south (left to right). Within the regions, in northern Africa, sites are sorted by longitude (west to east), while all other regions are sorted internally by latitude. All individual analyses are plotted as grey diamonds, upper and lower hinges of the boxes represent $75 \%$ and $25 \%$ quantiles, the horizontal line inside the boxes represents the median ( $50 \%$ quantile). Upper and lower whiskers show the highest and lowest measured values excluding outliers. Analyses with values higher than the $75 \%$ quantile plus 1.5 times the interquartile range (distance between first and third quartiles) or lower than the $25 \%$ quantile minus 1.5 times the interquartile range are considered outliers. The solid vertical line separates sites on the northern hemisphere (left) from sites on the southern hemisphere (right); sites between the dashed lines are located within the tropics. The width of the boxes is scaled to the number of analyses included in each boxplot. The only records from SISAL_v1 that were excluded from this plot are the normalized stable isotope records from Grotte de Piste.

Within records, the largest range of $\delta^{13} \mathrm{C}$ values is recorded in northern Madagascar and is attributed to a $C_{3}$ to $C_{4}$ vegetation shift due to human induced land-use change at 900 CE [14]. The isotopic result is supported by pollen records from lake cores on the island [107,142,160].

Spatial analysis of the isotopic patterns in African speleothems provides more information on changing climatic phenomena than point-source paleoclimate records. The changing northern African precipitation isoscape over the last 12,000 years (Figure 7) shows mixed conditions at the start of the Holocene $(12-11 \mathrm{ka})$, more negative $\delta^{18} \mathrm{O}$ in the early Holocene (11-6 ka) followed by more 
positive $\delta^{18} \mathrm{O}$ and a mixed response between sites in the late Holocene (4-0 ka). If more negative $\delta^{18} \mathrm{O}$ is interpreted as wetter conditions the timing and spatial pattern agrees well with the African Humid Period.
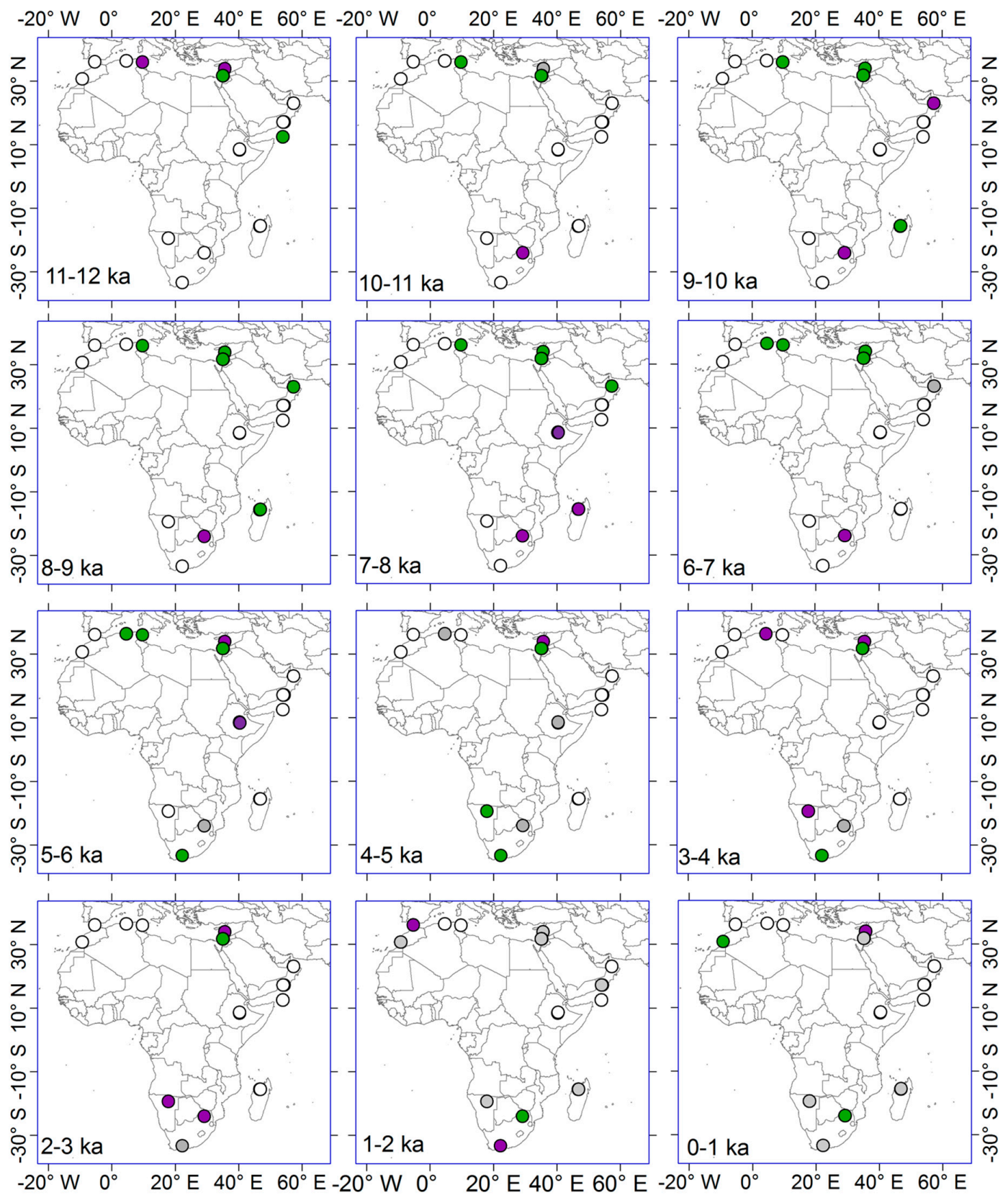

Figure 7. African speleothem isotope variability during the last 12,000 years. All plots show mean $\delta^{18} \mathrm{O}$ in 1000 -year bins. Colours indicate positive $\delta^{18} \mathrm{O}$ (purple), negative $\delta^{18} \mathrm{O}$ (green), low mean $\delta^{18} \mathrm{O}$ or multiple speleothems at one cave showing contrasting results (grey), or no recorded speleothem growth (white).

The southern hemisphere isoscape is more complicated. An antiphase response to the African Humid Period with dry conditions resulting from a more northerly tropical rainbelt is supported by more positive $\delta^{18} \mathrm{O}$ values between 11 and $6 \mathrm{ka}$ in southern Africa. However, this interpretation is reliant on just one long isotopic record, Cold Air Cave, and/or the interpretation of a lack of growth at other sites as indicating dry conditions, so we do not consider this result robust. The regional variation is more complex with Madagascan speleothem $\delta^{18} \mathrm{O}$ indicating possibly wet conditions between 11 
and $8 \mathrm{ka}$. Whether this complexity is due to southern hemisphere Africa having a more geographically variable regional climate, or due to the lack of records is uncertain. More southern hemisphere African speleothem records covering the late Holocene are required to make robust conclusions.

\section{Discussion of Future Research Directions}

There is great potential for speleothem studies to contribute to open questions concerning African palaeoclimates. As African speleothem records are temporally flashy, continued research should combine these snapshots with other longer term, lower resolution hydroclimate records such as sediment cores from lakes and near shore marine environments [104,137,161-163]. There are three key paleoclimate questions in Africa where future speleothem research could contribute:

- Interhemispheric teleconnection vs. see-saw: Paleoclimate proxy records from southern and eastern Africa show a complex pattern with some southern hemisphere sites suggesting wet phases during northern hemisphere warm intervals, while others suggest that northern hemisphere cold phases were wet in southern/southeastern Africa [15,164-166].

- The expansion and contraction of desert regions in both hemispheres, the Sahara in the north and Kalahari/Namib in the south: Speleothems can be used to investigate changes in the availability of moisture in regions that are now deserts or close to desert areas [46,58,61].

- Africa is home to the origins of humanity, in both early hominin evolution and the beginnings of cultural modernity: Speleothems from palaeoanthropological and archaeological sites, preserving remains and artefacts of early hominins, as well as modern humans, have been used for dating and the reconstruction of climates $[10,30,59,167,168]$. Further studies can improve our understanding of the interactions between early hominins and modern humans and their environments, their ability to adapt to climatic variations and the conditions leading to migrations such as the dispersal out of Africa.

Additional research targets include: increasing the number of African records in the SISAL database for more substantial data analysis and efforts to reanalyse materials that were sampled in the 1980s and 1990s, increasing dating accuracies and sampling resolutions of proxies and / or using new proxy methods. There are also large areas of Africa with significant karst regions that remain unexplored, such as western Africa, Angola, Tanzania and central Africa with enormous potential for speleothem research.

We have focused on U-Th dated speleothem records but longer records could be obtained using $\mathrm{U}-\mathrm{Pb}$ dating. The possibility to obtain records millions of years old is particularly pertinent in Africa given the wealth and antiquity of the fossil and archaeological record of human evolution. U-Pb dated speleothems from early hominin bearing caves sites, in areas such as the Cradle of Humankind in South Africa, opens up the possibility of looking at the relationship between hominin evolution and changes in the past hydroclimate through a local, terrestrial and directly dated archive.

\section{Conclusions}

The number of speleothem studies across large parts of Africa is very low because of restrictive bedrock geology and dry climate (Figure 1). Speleothem deposition at the southern and northern extremities of the present day ITCZ migration appears to be more common during late Pleistocene interglacials than during glacial phases, suggesting an overall increased latitudinal range of ITCZ migration or a widening of the tropical rainfall belt during interglacials. During glacial phases, speleothem deposition is recorded mainly in the hemisphere that has higher summer insolation. Due to the low number of samples and scattered spatial distribution, speleothem records do not yield a reliable picture of how the African equatorial regions are affected by the changes in the latitudinal range of the ITCZ.

Author Contributions: The first draft of the paper was written by K.B. with input from all other authors. All authors contributed to manuscript editing and revisions. 
Funding: This research received no external funding

Acknowledgments: SISAL is a working group of the Past Global Changes (PAGES) programme, and we thank PAGES for their support for this initiative. We would like to especially thank the SISAL members and our speleo-colleagues for contributing their published data to the database and providing additional information when necessary. Specifically, we wish to thank Andy Baker for assisting with the Ethiopia stalagmite section and Jessica von der Meden for accessing some obscure South African literature. We thank the World Karst Aquifer Mapping project (WOKAM) team for providing us with the karst region map presented in Figure 1, and Laia Comas Bru for the background for Figure 1. Thanks also to Sandy Harrison and Laia Comas Bru for their editorial handling and two anonymous reviewers for their constructive and useful comments.

Conflicts of Interest: The authors declare no conflict of interest.

\section{References}

1. Atsawawaranunt, K.; Harrison, S.; Comas Bru, L. SISAL (Speleothem Isotopes Synthesis and Analysis Working Group) Database Version 1.0. 2018. Available online: http://researchdata.reading.ac.uk/139/ (accessed on 10 May 2018).

2. Atsawawaranunt, K.; Comas-Bru, L.; Amirnezhad Mozhdehi, S.; Deininger, M.; Harrison, S.P.; Baker, A.; Boyd, M.; Kaushal, N.; Ahmad, S.M.; Ait Brahim, Y.; et al. The SISAL database: A global resource to document oxygen and carbon isotope records from speleothems. Earth Syst. Sci. Data 2018, 10, 1687-1713. [CrossRef]

3. Chen, Z.; Auler, A.S.; Bakalowicz, M.; Drew, D.; Griger, F.; Hartmann, J.; Jiang, G.; Moosdorf, N.; Richts, A.; Stevanovic, Z.; et al. The World Karst Aquifer Mapping project: Concept, mapping procedure and map of Europe. Hydrogeol. J. 2017, 25, 771-785. [CrossRef]

4. UNEP. Africa: Atlas of Our Changing Environment; Division of Early Warning and Assessment (DEWA); United Nations Environment Programme (UNEP): New York, NY, USA, 2008; ISBN 978-92-807-2871-2.

5. Talma, A.S.; Vogel, J.C. Late Quaternary Paleotemperatures derived from a Speleothem from Cango Caves, Cape Province, South Africa. Quat. Res. 1992, 37, 203-213. [CrossRef]

6. Talma, A.S.; Vogel, J.C.; Partridge, T.C. Isotopic contents of some Transvaal speleothems and their palaeoclimatic significance. S. Afr. J. Sci. 1974, 70, 135-140.

7. Woodhead, J.; Hellstrom, J.; Maas, R.; Drysdale, R.; Zanchetta, G.; Devine, P.; Taylor, E. U-Pb geochronology of speleothems by MC-ICPMS. Quat. Geochronol. 2006, 1, 208-221. [CrossRef]

8. Walker, J.; Cliff, R.A.; Latham, A.G. U-Pb isotopic age of the StW 573 hominid from Sterkfontein, South Africa. Science 2006, 314, 1592-1594. [CrossRef] [PubMed]

9. Pickering, R.; Herries, A.I.R.; Woodhead, J.D.; Hellstrom, J.C.; Green, H.E.; Paul, P.; Ritzman, T.; Strait, D.S.; Schoville, B.J.; Hancox, P.J. U-Pb dated flowstones restrict South African early hominin record to dry climate phases. Nature 2019, 565, 226-229. [CrossRef] [PubMed]

10. Hopley, P.J.; Weedon, G.P.; Marshall, J.D.; Herries, A.I.R.; Latham, A.G.; Kuykendall, K.L. High- and low-latitude orbital forcing of early hominin habitats in South Africa. Earth Planet. Sci. Lett. 2007, 256, 419-432. [CrossRef]

11. Hopley, P.J.; Marshall, J.D.; Weedon, G.P.; Latham, A.G.; Herries, A.I.R.; Kuykendall, K.L. Orbital forcing and the spread of $\mathrm{C} 4$ grasses in the late Neogene: Stable isotope evidence from South African speleothems. J. Hum. Evol. 2007, 53, 620-634. [CrossRef] [PubMed]

12. Asrat, A.; Baker, A.; Mohammed, M.U.; Leng, M.J.; Calsteren, P.V.; Smith, C. A high-resolution multi-proxy stalagmite record from Mechara, Southeastern Ethiopia: Palaeohydrological implications for speleothem palaeoclimate reconstruction. J. Quat. Sci. 2007, 22, 53-63. [CrossRef]

13. Brook, G.A.; Cowart, J.B.; Brandt, S.A.; Scott, L. Quaternary climatic change in southern and eastern Africa during the last $300 \mathrm{ka}$ : The evidence from caves in Somalia and the Transvaal region of South Africa. Z. Geomorphol. 1997, 108, 15-48.

14. Burns, S.J.; Godfrey, L.R.; Faina, P.; McGee, D.; Hardt, B.; Ranivoharimanana, L.; Randrianasy, J. Rapid human-induced landscape transformation in Madagascar at the end of the first millennium of the Common Era. Quat. Sci. Rev. 2016, 134, 92-99. [CrossRef]

15. Scroxton, N.; Burns, S.J.; McGee, D.; Hardt, B.; Godfrey, L.R.; Ranivoharimanana, L.; Faina, P. Hemispherically in-phase precipitation variability over the last 1700 years in a Madagascar speleothem record. Quat. Sci. Rev. 2017, 164, 25-36. [CrossRef] 
16. Voarintsoa, N.R.G.; Wang, L.; Railsback, L.B.; Brook, G.A.; Liang, F.; Cheng, H.; Edwards, R.L. Multiple proxy analyses of a U/Th-dated stalagmite to reconstruct paleoenvironmental changes in northwestern Madagascar between 370 CE and 1300 CE. Palaeogeogr. Palaeoclimatol. Palaeoecol. 2017, 469, 138-155. [CrossRef]

17. Voarintsoa, N.R.G.; Railsback, L.B.; Brook, G.A.; Wang, L.; Kathayat, G.; Cheng, H.; Li, X.; Edwards, R.L.; Rakotondrazafy, A.F.M.; Madison Razanatseheno, M.O. Three distinct Holocene intervals of stalagmite deposition and nondeposition revealed in NW Madagascar, and their paleoclimate implications. Clim. Past 2017, 13, 1771-1790. [CrossRef]

18. Brook, G.A.; Rafter, M.A.; Railsback, L.B.; Sheen, S.-W.; Lundberg, J. A high-resolution proxy record of rainfall and ENSO since AD 1550 from layering in stalagmites from Anjohibe Cave, Madagascar. Holocene 1999, 9, 695-705. [CrossRef]

19. Voarintsoa, N.R.G.; Brook, G.A.; Liang, F.; Marais, E.; Hardt, B.; Cheng, H.; Edwards, R.L.; Railsback, L.B. Stalagmite multi-proxy evidence of wet and dry intervals in northeastern Namibia: Linkage to latitudinal shifts of the Inter-Tropical Convergence Zone and changing solar activity from AD 1400 to 1950. Holocene 2017, 27, 384-396. [CrossRef]

20. Baker, A.; Asrat, A.; Fairchild, I.J.; Leng, M.J.; Thomas, L.; Widmann, M.; Jex, C.N.; Dong, B.; van Calsteren, P.; Bryant, C. Decadal-scale rainfall variability in Ethiopia recorded in an annually laminated, Holocene-age, stalagmite. Holocene 2010, 20, 827-836. [CrossRef]

21. Railsback, L.B.; Brook, G.A.; Liang, F.; Voarintsoa, N.R.G.; Cheng, H.; Edwards, R.L. A multi-proxy climate record from a northwestern Botswana stalagmite suggesting wetness late in the Little Ice Age (1810-1820 CE) and drying thereafter in response to changing migration of the tropical rain belt or ITCZ. Palaeogeogr. Palaeoclimatolol. Palaeoecol. 2018, 506, 139-153. [CrossRef]

22. Vogel, J.C.; Kronfeld, J. Calibration of Radiocarbon Dates for the Late Pleistocene using U/Th Dates of Stalagmites. Radiocarbon 1997, 39, 27-32. [CrossRef]

23. Vogel, J.C. ${ }^{14} \mathrm{C}$ Variations during the Upper Pleistocene. Radiocarbon 1983, 25, 213-218. [CrossRef]

24. Van Rampelbergh, M.; Fleitmann, D.; Verheyden, S.; Cheng, H.; Edwards, L.; De Geest, P.; DeVleeschouwer, D.; Burns, S.J.; Matter, A.; Claeys, P.; et al. Mid- to late Holocene Indian Ocean Monsoon variability recorded in four speleothems from Socotra Island, Yemen. Quat. Sci. Rev. 2013, 65, 129-142. [CrossRef]

25. Repinski, P.; Holmgren, K.; Lauritzen, S.-E.; Lee-Thorp, J.A. A late Holocene climate record from a stalagmite, Cold Air Cave, Northern Province, South Africa. Palaeogeogr. Palaeoclimatol. Palaeoecol. 1999, 150, $269-277$. [CrossRef]

26. Holmgren, K.; Karlén, W.; Svanered, O.; Lauritzen, S.-E.; Lee-Thorp, J.A.; Partridge, T.C.; Piketh, S.; Tyson, P.D. A 3000-year high-resolution stalagmite-based record of palaeoclimate for northeastern South Africa. Holocene 1999, 9, 295-309. [CrossRef]

27. Stevenson, C.; Lee-Thorp, J.A.; Holmgren, K. A 3000-year isotopic record from a stalagmite in Cold Air Cave, Makapansgat Valley, Northern Province. S. Afr. J. Sci. 1999, 95, 46-48.

28. Brook, G.A. Stratigraphic evidence of quaternary climatic change at Echo Cave, Transvaal, and a paleoclimatic record for Botswana and northeastern South Africa. Catena 1982, 9, 343-351. [CrossRef]

29. Holmgren, K.; Lee-Thorp, J.A.; Cooper, G.R.J.; Lundblad, K.; Partridge, T.C.; Scott, L.; Sithaldeen, R.; Talma, A.S.; Tyson, P.D. Persistent millennial-scale climatic variability over the past 25,000 years in Southern Africa. Quat. Sci. Rev. 2003, 22, 2311-2326. [CrossRef]

30. Bar-Matthews, M.; Marean, C.W.; Jacobs, Z.; Karkanas, P.; Fisher, E.C.; Herries, A.I.R.; Brown, K.S.; Williams, H.M.; Bernatchez, J.A.; Ayalon, A.; et al. A high resolution and continuous isotopic speleothem record of paleoclimate and paleoenvironment from 90-53 ka from Pinnacle Point on the south coast of South Africa. Quat. Sci. Rev. 2010, 29, 2131-2145. [CrossRef]

31. Slettern, H.R.; Railsback, L.B.; Liang, F.; Brook, G.A.; Marais, E.; Hardt, B.F.; Cheng, H.; Edwards, R.L. A petrographic and geochemical record of climate change over the last 4600 years from a northern Namibia stalagmite, with evidence of abruptly wetter climate at the beginning of southern Africa's Iron Age. Palaeogeogr. Palaeoclimatol. Palaeoecol. 2013, 376, 149-162. [CrossRef]

32. Railsback, L.B.; Brook, G.A.; Liang, F.; Marais, E.; Cheng, H.; Edwards, R. A multi-proxy stalagmite record from northwestern Namibia of regional drying with increasing global-scale warmth over the last $47 \mathrm{kyr}$ : The interplay of a globally shifting ITCZ with regional currents, winds, and rainfall. Palaeogeogr. Palaeoclimatol. Palaeoecol. 2016, 461, 109-121. [CrossRef] 
33. Burns, S.J.; Fleitmann, D.; Mudelsee, M.; Neff, U.; Matter, A.; Mangini, A. A 780-year annually resolved record of Indian Ocean monsoon precipitation from a speleothem from south Oman. J. Geophys. Res. 2002, 107. [CrossRef]

34. Fleitmann, D.; Burns, S.J.; Mangini, A.; Mudelsee, M.; Kramers, J.; Villa, I.; Neff, U.; Al-Subbary, A.A.; Buettner, A.; Hippler, D.; et al. Holocene ITCZ and Indian monsoon dynamics recorded in stalagmites from Oman and Yemen (Socotra). Quat. Sci. Rev. 2007, 26, 170-188. [CrossRef]

35. Cooke, H.J.; Verhagen, B.T. The dating of cave development-An example from Botswana. In Proceedings of the 7th International Speleological Congress Sheffield, England, UK, 10-17 September 1977; pp. 122-124.

36. Cooke, H.J. The Palaeoclimatic Significance of Caves and Adjacent Landforms in Western Ngamiland, Botswana. Geogr. J. 1975, 141, 430-444. [CrossRef]

37. Shaw, P.A.; Cooke, H.J. Geomorphic evidence for the late Quaternary palaeoclimates of the middle Kalahari of northern Botswana. Catena 1986, 13, 349-359. [CrossRef]

38. Heine, K. On the ages of humid Late Quaternary phases in southern African arid areas (Namibia, Botswana). Palaeoecol. Afr. Surround. Isl. 1992, 23, 149-164.

39. Brook, G.A.; Burney, D.A.; Cowart, J.B. Desert paleoenvironmental data from cave speleothems with examples from the Chihuahuan, Solmali-Chalbi, and Kalahari deserts. Palaeogeogr. Palaeoclimatol. Palaeoecol. 1990, 76, 311-329. [CrossRef]

40. Pickering, R.; Hancox, P.J.; Lee-Thorp, J.A.; Grün, R.; Graham, E.M.; McCulloch, M.T.; Berger, L.R. Stratigraphy, U-Th chronology, and paleoenvironments at Gladysvale Cave: Insights into the climatic control of South African hominin-bearing cave deposits. J. Hum. Evol. 2007, 53, 602-619. [CrossRef] [PubMed]

41. Asrat, A.; Baker, A.; Leng, M.J.; Hellstrom, J.; Mariethozm, G.; Boomer, I.; Yu, D.; Jex, C.N.; Gunn, J. Paleoclimate change in Ethiopia around the last interglacial derived from annually-resolved stalagmite evidence. Quat. Sci. Rev. 2018, 202, 197-210. [CrossRef]

42. Wassenburg, J.A.; Dietrich, S.; Fietzke, J.; Fohlmeister, J.; Jochum, K.P.; Scholz, D.; Richter, D.K.; Sabaoui, A.; Spötl, C.; Lohmann, G.; et al. Reorganization of the North Atlantic Oscillation during early Holocene deglaciation. Nat. Geosci. 2016, 9, 602. [CrossRef]

43. Wassenburg, J.A.; Immenhauser, A.; Richter, D.K.; Jochum, K.P.; Fietzke, J.; Deininger, M.; Goos, M.; Scholz, D.; Sabaoui, A. Climate and cave control on Pleistocene/Holocene calcite-to-aragonite transitions in speleothems from Morocco: Elemental and isotopic evidence. Geochim. Cosmochim. Acta 2012, 92, $23-47$. [CrossRef]

44. Ruan, J.; Kherbouche, F.; Genty, D.; Blamart, D.; Cheng, H.; Dewilde, F.; Hachi, S.; Edwards, R.; Régnier, E.; Michelot, J.-L. Evidence of a prolonged drought ca. $4200 \mathrm{yr}$ BP correlated with prehistoric settlement abandonment from the Gueldaman GLD1 cave, Northern Algeria. Clim. Past 2016, 12, 1-14. [CrossRef]

45. Neff, U.; Burns, S.J.; Mangini, A.; Mudelsee, M.; Fleitmann, D.; Matter, A. Strong coherence between solar variability and the monsoon in Oman between 9 and 6 kyr ago. Nature 2001, 411, 290-293. [CrossRef] [PubMed]

46. Burns, S.J.; Fleitmann, D.; Matter, A.; Neff, U.; Mangini, A. Speleothem evidence from Oman for continental pluvial events during interglacial periods. Geology 2001, 29, 623-626. [CrossRef]

47. Fleitmann, D.; Burns, S.J.; Neff, U.; Mangini, A.; Matter, A. Changing moisture sources over the last 330,000 years in Northern Oman from fluid-inclusion evidence in speleothems. Quat. Res. 2003, 60, 223-232. [CrossRef]

48. Burns, S.J.; Matter, A.; Frank, N.; Mangini, A. Speleothem-based paleoclimate record from northern Oman. Geology 1998, 26, 499. [CrossRef]

49. Ait Brahim, Y.; Cheng, H.; Sifeddine, A.; Wassenburg, J.A.; Cruz, F.W.; Khodri, M.; Sha, L.; Pérez-Zanón, N.; Beraaouz, E.H.; Apaéstegui, J.; et al. Speleothem records decadal to multidecadal hydroclimate variations in southwestern Morocco during the last millennium. Earth Planet. Sci. Lett. 2017, 476, 1-10. [CrossRef]

50. Lundblad, K.; Holmgren, K. Palaeoclimatological survey of stalagmites from coastal areas in Tanzania. Geogr. Ann. Ser. A Phys. Geogr. 2005, 87, 125-140. [CrossRef]

51. Genty, D.; Blamart, D.; Ghaleb, B.; Plagnes, V.; Causse, C.; Bakalowicz, M.; Zouari, K.; Chkir, N.; Hellstrom, J.; Wainer, K.; et al. Timing and dynamics of the last deglaciation from European and North African $\delta^{13} \mathrm{C}$ stalagmite profiles-comparison with Chinese and South Hemisphere stalagmites. Quat. Sci. Rev. 2006, 25, 2118-2142. [CrossRef] 
52. Holmgren, K.; Karlén, W.; Shaw, P.A. Paleoclimatic Significance of the Stable Isotopic Composition and Petrology of a Late Pleistocene Stalagmite from Botswana. Quat. Res. 1995, 43, 320-328. [CrossRef]

53. Holmgren, K.; Lauritzen, S.-E.; Possnert, G. ${ }^{230} \mathrm{Th} /{ }^{234} \mathrm{U}$ and ${ }^{14} \mathrm{C}$ dating of a late Pleistocene stalagmite in Lobatse II Cave, Botswana. Quat. Sci. Rev. 1994, 13, 111-119. [CrossRef]

54. Goslar, T.; Hercman, H.; Pazdur, A. Comparison of U-Series and Radiocarbon Dates of Speleothems. Radiocarbon 2000, 42, 403-414. [CrossRef]

55. Hennig, G.J.; Grün, R.; Brunnacker, K. Speleothems, travertines, and paleoclimates. Quat. Res. 1983, $20,1-29$. [CrossRef]

56. Shakun, J.D.; Burns, S.J.; Fleitmann, D.; Kramers, J.; Matter, A.; Al-Subary, A. A high-resolution, absolute-dated deglacial speleothem record of Indian Ocean climate from Socotra Island, Yemen. Earth Planet. Sci. Lett. 2007, 259, 442-456. [CrossRef]

57. Burns, S.J.; Fleitmann, D.; Matter, A.; Kramers, J.; Al-Subbary, A.A. Indian Ocean Climate and an Absolute Chronology over Dansgaard/Oeschger Events 9 to 13. Science 2003, 301, 1365-1367. [CrossRef] [PubMed]

58. Fleitmann, D.; Burns, S.J.; Pekala, M.; Mangini, A.; Al-Subbary, A.; Al-Aowah, M.; Kramers, J.; Matter, A. Holocene and Pleistocene pluvial periods in Yemen, southern Arabia. Quat. Sci. Rev. 2011, 30, 783-787. [CrossRef]

59. Braun, K.; Bar-Matthews, M.; Matthews, A.; Ayalon, A.; Cowling, R.M.; Karkanas, P.; Fisher, E.C.; Dyez, K.A.; Zilberman, T.; Marean, C.W. Late Pleistocene records of speleothem stable isotopic compositions from Pinnacle Point on the South African south coast show close climate connection with rainfall in the interior. Quat. Res. 2018, 1-24. [CrossRef]

60. Fleitmann, D.; Burns, S.J.; Mudelsee, M.; Neff, U.; Kramers, J.; Mangini, A.; Matter, A. Holocene Forcing of the Indian Monsoon Recorded in a Stalagmite from Southern Oman. Science 2003, 300, 1737-1739. [CrossRef] [PubMed]

61. Geyh, M.A.; Heine, K. Several distinct wet periods since $420 \mathrm{ka}$ in the Namib Desert inferred from U-series dates of speleothems. Quat. Res. 2014, 81, 381-391. [CrossRef]

62. Green, H.; Pickering, R.; Drysdale, R.N.; Johnson, B.C.; Hellstrom, J.C.; Wallace, M. Evidence for global teleconnections in a late Pleistocene speleothem record of water balance and vegetation change at Sudwala Cave, South Africa. Quat. Sci. Rev. 2015, 110, 114-130. [CrossRef]

63. Hoffmann, D.L.; Rogerson, M.; Spötl, C.; Luetscher, M.; Vance, D.; Osborne, A.H.; Fello, N.M.; Moseley, G.E. Timing and causes of North African wet phases during MIS 3 and implications for Modern Human migration. Nat. Sci. Rep. 2016, 6, 36367. [CrossRef] [PubMed]

64. Rifai, R.I. Reconstruction of the Middle Pleistocene climate of south Mediterranean using the Wadi Sannur speleothem, eastern Desert, Egypt. Carbonates Evaporites 2007, 22, 73. [CrossRef]

65. El-Shenawy, M.I.; Kim, S.-T.; Schwarcz, H.P.; Asmerom, Y.; Polyak, V.J. Speleothem evidence for the greening of the Sahara and its implications for the early human dispersal out of sub-Saharan Africa. Quat. Sci. Rev. 2018, 188, 67-76. [CrossRef]

66. Holzkämper, S.; Holmgren, K.; Lee-Thorp, J.A.; Talma, A.S.; Mangini, A.; Partridge, T.C. Late Pleistocene stalagmite growth in Wolkberg Cave, South Africa. Earth Planet. Sci. Lett. 2009, 282, 212-221. [CrossRef]

67. Brook, G.A.; Scott, L.; Railsback, L.B.; Goddard, E.A. A 35 ka pollen and isotope record of environmental change along the southern margin of the Kalahari from a stalagmite and animal dung deposits in Wonderwerk Cave, South Africa. J. Arid Environ. 2010, 74, 870-884. [CrossRef]

68. Chase, B.M.; Chevalier, M.; Boom, A.; Carr, A.S. The dynamic relationship between temperate and tropical circulation systems across South Africa since the last glacial maximum. Quat. Sci. Rev. 2017, 174, 54-62. [CrossRef]

69. Di Nezio, P.N.; Timmermann, A.; Tierney, J.E.; Jin, F.-F.; Otto-Bliesner, B.; Rosenbloom, N.; Mapes, B.; Neale, R.; Ivanovic, R.F.; Montenegro, A. The climate response of the Indo-Pacific warm pool to glacial sea level. Paleoceanography 2016, 31, 866-894. [CrossRef]

70. Dezfuli, A.K.; Zaitchik, B.F.; Gnanadesikan, A. Regional atmospheric circulation and rainfall variability in south equatorial Africa. J. Clim. 2015, 28, 809-818. [CrossRef]

71. Knippertz, P.; Christoph, M.; Speth, P. Long-term precipitation variability in Morocco and the link to the large-scale circulation in recent and future climates. Meteorol. Atmos. Phys. 2003, 83, 67-88. [CrossRef]

72. Rohling, E.J.; Marino, G.; Grant, K.M. Mediterranean climate and oceanography, and the periodic development of anoxic events (sapropels). Earth-Sci. Rev. 2015, 143, 62-97. [CrossRef] 
73. Raicich, F.; Pinardi, N.; Navarra, A. Teleconnections between Indian monsoon and Sahel rainfall and the Mediterranean. Int. J. Climatol. 2003, 23, 173-186. [CrossRef]

74. De Menocal, P.; Ortiz, J.; Guilderson, T.; Adkins, J.; Sarnthein, M.; Baker, L.; Yarusinsky, M. Abrupt onset and termination of the African Humid Period: Rapid climate responses to gradual insolation forcing. Quat. Sci. Rev. 2000, 19, 347-361. [CrossRef]

75. Armitage, S.J.; Drake, N.A.; Stokes, S.; El-Hawat, A.; Salem, M.J.; White, K.; Turner, P.; McLaren, S.J. Multiple phases of North African humidity recorded in lacustrine sediments from the Fazzan Basin, Libyan Sahara. Quat. Geochronol. 2007, 2, 181-186. [CrossRef]

76. Nicoll, K. Recent environmental change and prehistoric human activity in Egypt and Northern Sudan. Quat. Sci. Rev. 2004, 23, 561-580. [CrossRef]

77. Hoelzmann, P.; Jolly, D.; Harrison, S.P.; Laarif, F.; Bonnefille, R.; Pachur, H.J. Mid-Holocene land-surface conditions in northern Africa and the Arabian Peninsula: A data set for the analysis of biogeophysical feedbacks in the climate system. Glob. Biogeochem. Cycles 1998, 12, 35-51. [CrossRef]

78. Swezey, C. Eolian sediment responses to late Quaternary climate changes: Temporal and spatial patterns in the Sahara. Palaeogeogr. Palaeoclimatol. Palaeoecol. 2001, 167, 119-155. [CrossRef]

79. Singarayer, J.S.; Burrough, S.L. Interhemispheric dynamics of the African rainbelt during the late Quaternary. Quat. Sci. Rev. 2015, 124, 48-67. [CrossRef]

80. Nicholson, S.E. The nature of rainfall variability over Africa on time scales of decades to millenia. Glob. Planet. Chang. 2000, 2, 137-158. [CrossRef]

81. Black, E.; Slingo, J.; Sperber, K.R. An Observational Study of the Relationship between Excessively Strong Short Rains in Coastal East Africa and Indian Ocean SST. Mon. Weather Rev. 2003, 131, 74-94. [CrossRef]

82. Goddard, L.; Graham, N.E. Importance of the Indian Ocean for simulating rainfall anomalies over eastern and southern Africa. J. Geophys. Res. 1999, 104, 19099-19116. [CrossRef]

83. Ummenhofer, C.C.; Sen Gupta, A.; England, M.H.; Reason, C.J.C. Contributions of Indian Ocean Sea Surface Temperatures to Enhanced East African Rainfall. Am. Meteorol. Soc. 2009, 22, 993-1013. [CrossRef]

84. Ummenhofer, C.C.; Kulüke, M.; Tierney, J.E. Extremes in East African hydroclimate and links to Indo-Pacific variability on interannual to decadal timescales. Clim. Dyn. 2017, 50, 2971-2991. [CrossRef]

85. Saji, N.H.; Goswami, B.N.; Vinayachandran, P.N.; Yamagata, T. A dipole mode in the tropical Indian Ocean. Nature 1999, 401, 360-363. [CrossRef] [PubMed]

86. Zinke, J.; Pfeiffer, M.; Timm, O.; Dullo, W.C.; Brummer, G.J.A. Western Indian Ocean marine and terrestrial records of climate variability: A review and new concepts on land-ocean interactions since AD 1660. Int. J. Earth Sci. 2009, 98, 115. [CrossRef]

87. Konecky, B.; Russell, J.M.; Vuille, M.; Rehfeld, K. The Indian Ocean Zonal Mode over the past millennium in observed and modeled precipitation isotopes. Quat. Sci. Rev. 2014, 103, 1-18. [CrossRef]

88. Weldeab, S.; Lea, D.W.; Oberhänsli, H.; Schneider, R.R. Links between southwestern tropical Indian Ocean SST and precipitation over southeastern Africa over the last 17 kyr. Palaeogeogr. Palaeoclimatol. Palaeoecol. 2014, 410, 200-212. [CrossRef]

89. Hansingo, K.; Reason, C.J.C. Modelling the atmospheric response to SST dipole patterns in the South Indian Ocean with a regional climate model. Meteorol. Atmos. Phys. 2008, 100, 37-52. [CrossRef]

90. Van Heerden, J.; Taljaard, J.J. Africa and Surrounding Waters. In Meteorology of the Southern Hemisphere; American Meteorological Society: Boston, MA, USA, 1998; pp. 141-174.

91. Engelbrecht, C.J.; Landman, W.A.; Engelbrecht, F.A.; Malherbe, J. A synoptic decomposition of rainfall over the Cape south coast of South Africa. Clim. Dyn. 2015, 44, 2589-2607. [CrossRef]

92. Fairchild, I.J.; Baker, A. Speleothem Science: From Process to Past Environments; John Wiley \& Sons: Chichester, UK, 2012; 432p, ISBN 978-1-4051-9620-8.

93. De Lamotte, D.F.; Leturmy, P.; Missenard, Y.; Khomsi, S.; Ruiz, G.; Saddiqi, O.; Guillocheau, F.; Michard, A. Mesozoic and Cenozoic vertical movements in the Atlas system (Algeria, Morocco, Tunisia): An overview. Tectonophysics 2009, 475, 9-28. [CrossRef]

94. Rohling, E.J.; De Rijk, S. Holocene Climate Optimum and Last Glacial Maximum in the Mediterranean: The marine oxygen isotope record. Mar. Geol. 1999, 153, 57-75. [CrossRef] 
95. Wassenburg, J.; Immenhauser, A.; Richter, D.; Niedermayr, A.; Riechelmann, S.; Fietzke, J.; Scholz, D.; Jochum, K.; Fohlmeister, J.; Schröder-Ritzrau, A. Moroccan speleothem and tree ring records suggest a variable positive state of the North Atlantic Oscillation during the Medieval Warm Period. Earth Planet. Sci. Lett. 2013, 375, 291-302. [CrossRef]

96. Fleitmann, D.; Burns, S.J.; Neff, U.; Mudelsee, M.; Mangini, A.; Matter, A. Palaeoclimatic interpretation of high-resolution oxygen isotope profiles derived from annually laminated speleothems from Southern Oman. Quat. Sci. Rev. 2004, 23, 935-945. [CrossRef]

97. Dansgaard, W.; Johnsen, S.J.; Clausen, H.B.; Dahl-Jensen, D.; Gundestrup, N.S.; Hammer, C.U.; Hvidberg, C.S. Evidence for general instability of past climate from a 250-kyr ice-core record. Nature 1993, 364, 218-220. [CrossRef]

98. Andersen, K.K.; Azuma, N.; Barnola, J.M.; Bigler, M.; Biscaye, P.; Caillon, N.; Chappellaz, J.; Clausen, H.B.; Dahl-Jensen, D.; Fischer, H.; et al. High-resolution climate record of Northern Hemisphere climate extending into the Last Interglacial period. Nature 2004, 431, 147-151. [CrossRef] [PubMed]

99. Baker, A.; Asrat, A.; Fairchild, I.J.; Leng, M.J.; Wynn, P.M.; Bryant, C.; Genty, D.; Umer, M. Analysis of the climate signal contained within $\delta^{18} \mathrm{O}$ and growth rate parameters in two Ethiopian stalagmites. Geochim. Cosmochim. Acta 2007, 71, 2975-2988. [CrossRef]

100. Asrat, A.; Baker, A.; Leng, M.J.; Gunn, J.; Umer, M. Environmental monitoring in the Mechara caves, Southeastern Ethiopia: Implications for speleothem palaeoclimate studies. Int. J. Speleol. 2008, 37, 207-220. [CrossRef]

101. Blyth, A.J.; Asrat, A.; Baker, A.; Gulliver, P.; Leng, M.J.; Genty, D. A new approach to detecting vegetation and land-use change using high-resolution lipid biomarker records in stalagmites. Quat. Res. 2007, 68, 314-324. [CrossRef]

102. Holmgren, K.; Karlén, W.; Lauritzen, S.E.; Lee Thorp, J.A.; Partridge, T.C.; Shaw, P.A.; Tyson, P.D. Speleochronology, stable isotopes and laminae analysis of stalagmites from southern Africa. In Proceedings of the International Congress on Speleology, La Chaux-de-Fond, Switzerland, 10-17 August 1997; Jeanin, P.-Y., Ed.; pp. 55-56.

103. Verschuren, D.; Laird, K.R.; Cumming, B.F. Rainfall and drought in equatorial east Africa during the past 1100 years (2000). Rainfall and drought in equatorial east Africa during the past 1100 years. Nature 2000, 403, 410-414. [CrossRef] [PubMed]

104. Tierney, J.E.; Smerdon, J.E.; Anchukaitis, K.J.; Seager, R. Multidecadal variability in East African hydroclimate controlled by the Indian Ocean. Nature 2013, 493, 389-392. [CrossRef] [PubMed]

105. Buckles, L.K.; Verschuren, D.; Weijers, J.W.; Cocquyt, C.; Blaauw, M.; Sinninghe Damsté, J.S. Interannual and (multi-) decadal variability in the sedimentary BIT index of Lake Challa, East Africa, over the past 2200 years: Assessment of the precipitation proxy. Clim. Past 2016, 12, 1243-1262. [CrossRef]

106. Burney, D.A. Late Holocene Vegetational Change in Central Madagascar. Quat. Res. 1987, 28, $130-143$. [CrossRef]

107. Matsumoto, K.; Burney, D.A. Late Holocene environments at Lake Mitsinjo, northwestern Madagascar. Holocene 1994, 4, 16-24. [CrossRef]

108. Carbol, P.; Coudray, J. Climatic fluctuations influence the genesis and diagenesis of carbonate speleothems in southwest France. Natl. Speleol. Soc. Bull. 1982, 44, 112-117.

109. Hopley, P.J.; Marshall, J.D.; Latham, A.G. Speleothem preservation and diagenesis in South African hominin sites: Implications for paleoenvironments and geochronology. Geoarchaeology 2009, 24, 519-547. [CrossRef]

110. Ortega, R.; Maire, R.; Devès, G.; Quinif, Y. High-resolution mapping of uranium and other trace elements in recristallized aragonite-calcite speleothems from caves in the Pyrenees (France): Implication for U-series dating. Earth Planet. Sci. Lett. 2005, 237, 911-923. [CrossRef]

111. Hopley, P.J.; Weedon, G.P.; Brierley, C.M.; Thrasivoulou, C.; Herries, A.I.R.; Dinckal, A.; Richards, D.A.; Nita, D.C.; Parrish, R.R.; Roberts, N.M.W.; et al. Orbital precession modulates interannual rainfall variability, as recorded in an Early Pleistocene speleothem. Geology 2018, 46, 731-734. [CrossRef]

112. Vogel, J.C.; Fuls, A. Spatial Distribution of Radiocarbon Dates for the Iron Age in Southern Africa. S. Afr. Archaeol. Bull. 1999, 54, 97-101. [CrossRef]

113. Sundqvist, H.S.; Holmgren, K.; Fohlmeister, J.; Zhang, Q.; Bar-Matthews, M.; Spötl, C.; Kornich, H. Evidence of a large cooling between 1690 and 1740 AD in southern Africa. Nat. Sci. Rep. 2013, 3, 1767. [CrossRef] 
114. Lee-Thorp, J.A.; Holmgren, K.; Lauritzen, S.-E.; Linge, H.; Moberg, A.; Partridge, T.C.; Stevenson, C.; Tyson, P.D. Rapid climate shifts in the southern African interior throughout the Mid to Late Holocene. Geophys. Res. Lett. 2001, 28, 4507-4510. [CrossRef]

115. Ayliffe, L.K.; Marianelli, P.C.; Moriarty, K.C.; Wells, R.T.; McCulloch, M.T.; Mortimer, G.E.; Hellstrom, J.C. 500 ka precipitation record from southeastern Australia: Evidence for interglacial relative aridity. Geology 1998, 26, 147-150. [CrossRef]

116. Braun, K.; Bar-Matthews, M.; Ayalon, A.; Zilberman, T.; Matthews, A. Rainfall isotopic variability at the intersection between winter and summer rainfall regimes in coastal South Africa (Mossel Bay, Western Cape Province). S. Afr. J. Geol. 2017, 120, 323-340. [CrossRef]

117. Scroxton, N.; Gagan, M.K.; Dunbar, G.B.; Ayliffe, L.K.; Hantoro, W.S.; Shen, C.C.; Hellstrom, J.C.; Zhao, J.X.; Cheng, H.; Edwards, R.L.; et al. Natural attrition and growth frequency variations of stalagmites in southwest Sulawesi over the past 530,000 years. Palaeogeogr. Palaeoclimatol. Palaeoecol. 2016, 441, 823-833. [CrossRef]

118. Zielhofer, C.; Fletcher, W.J.; Mischke, S.; De Batist, M.; Campbell, J.F.; Joannin, S.; Tjallingii, R.; El Hamouti, N.; Junginger, A.; Stele, A.; et al. Atlantic forcing of Western Mediterranean winter rain minima during the last 12,000 years. Quat. Sci. Rev. 2017, 157, 29-51. [CrossRef]

119. Jouzel, J.; Masson-Delmotte, V.; Cattani, O.; Dreyfus, G.; Falourd, S.; Hoffmann, G.; Minster, B.; Nouet, J.; Barnola, J.M.; Chappellaz, J.; et al. Orbital and millennial Antarctic climate variability over the past 800,000 years. Science 2007, 317, 793-796. [CrossRef] [PubMed]

120. International Atomic Energy Agency. Isotope techniques in the study of environmental change. In Proceedings of the International Symposium on Isotope Techniques in the Study of Past and Current Environmental Changes in the Hydrosphere and the Atmosphere, International Atomic Energy Agency, Vienna, Austria, 14-18 April 1997; IAEA: Vienna, Austria, 1997; p. 936.

121. Leblanc, M.J.; Leduc, C.; Stagnitti, F.; Van Oevelen, P.J.; Jones, C.; Mofor, L.A.; Razack, M.; Favreau, G. Evidence for Megalake Chad, north-central Africa, during the late Quaternary from satellite data. Palaeogeogr. Palaeoclimatol. Palaeoecol. 2006, 230, 230-242. [CrossRef]

122. Ghoneim, E.; El-Baz, F. DEM-optical-radar data integration for palaeohydrological mapping in the northern Darfur, Sudan: Implication for groundwater exploration. Int. J. Remote Sens. 2007, 28, 5001-5018. [CrossRef]

123. Conrad, G.; Lappartient, J.-R. The appearance of Cardium fauna and foraminifers in the great lakes of the early quaternary period in the Algerian central Sahara Desert. J. Afr. Earth Sci. (Middle East) 1991, 12, 375-382. [CrossRef]

124. Quade, J.; Dente, E.; Armon, M.; Ben Dor, Y.; Morin, E.; Adam, O.; Enzel, Y. Megalakes in the Sahara? A Review. Quat. Res. 2018, 90, 253-275. [CrossRef]

125. Drake, N.A.; Lem, R.E.; Armitage, S.J.; Breeze, P.; Francke, J.; El-Hawat, A.S.; Salem, M.J.; Hounslow, M.W.; White, K. Reconstructing palaeoclimate and hydrological fluctuations in the Fezzan Basin (southern Libya) since 130 ka: A catchment-based approach. Quat. Sci. Rev. 2018, 200, 376-394. [CrossRef]

126. Cremaschi, M.; Zerboni, A.; Spötl, C.; Felletti, F. The calcareous tufa in the Tadrart Acacus Mt. (SW Fezzan, Libya): An early Holocene palaeoclimate archive in the central Sahara. Palaeogeogr. Palaeoclimatol. Palaeoecol. 2010, 287, 81-94. [CrossRef]

127. Smith, J.R.; Giegengack, R.; Schwarcz, H.P.; McDonald, M.M.; Kleindienst, M.R.; Hawkins, A.L.; Churcher, C.S. A reconstruction of quaternary pluvial environments and human occupations using stratigraphy and geochronology of fossil-spring tufas, Kharga Oasis, Egypt. Geoarchaeol. Int. J. 2004, 19, 407-439. [CrossRef]

128. Laskar, J.; Robutel, P.; Joutel, F.; Gastineau, M.; Correia, A.C.M.; Levrard, B. A long-term numerical solution for the insolation quantities of the Earth. Astron. Astrophys. 2004, 428, 261-285. [CrossRef]

129. Larrasoaña, J.C.; Roberts, A.P.; Hayes, A.; Wehausen, R.; Rohling, E.J. Detecting missing beats in the Mediterranean climate rhythm from magnetic identification of oxidized sapropels (Ocean Drilling Program Leg 160). Phys. Earth Planet. Inter. 2006, 156, 283-293. [CrossRef]

130. Zanchetta, G.; Bar-Matthews, M.; Drysdale, R.N.; Lionello, P.; Ayalon, A.; Hellstrom, J.C.; Isola, I.; Regattieri, E. Coeval dry events in the central and eastern Mediterranean basin at 5.2 and 5.6 ka recorded in Corchia (Italy) and Soreq caves (Israel) speleothems. Glob. Planet. Chang. 2014, 122, 130-139. [CrossRef]

131. Drysdale, R.N.; Zanchetta, G.; Hellstrom, J.; Maas, R.; Fallick, A.; Pickett, M.; Cartwright, I.; Piccini, L. Late Holocene drought responsible for the collapse of Old World civilizations is recorded in an Italian cave flowstone. Geology 2006, 34, 101-104. [CrossRef] 
132. Bar-Matthews, M.; Ayalon, A. Mid-Holocene climate variations revealed by high-resolution speleothem records from Soreq Cave, Israel and their correlation with cultural changes. Holocene 2011, 21, 163-171. [CrossRef]

133. Kaufman, A.J.; Wasserburg, G.J.; Porcelli, D.; Bar-Matthews, M.; Ayalon, A.; Halicz, L. U-Th isotope systematics from the Soreq cave, Israel and climatic correlations. Earth Planet. Sci. Lett. 1998, 156, 141-155. [CrossRef]

134. Weyhenmeyer, C.E.; Burns, S.J.; Waber, H.N.; Aeschbach-Hertig, W.; Kipfer, R.; Loosli, H.H.; Matter, A. Cool Glacial Temperatures and Changes in Moisture Source Recorded in Oman Groundwaters. Science 2000, 287, 842-845. [CrossRef] [PubMed]

135. Stager, J.C.; Mayewski, P.A. Abrupt Early to Mid-Holocene Climatic Transition registered at the Equator and the Poles. Science 1997, 276, 1834-1836. [CrossRef]

136. Tierney, J.E.; Russell, J.M.; Huang, Y.; Sinninghe Damsté, J.S.; Hopmans, E.C.; Cohen, A.S. Northern Hemisphere Controls on Tropical Southeast African Climate During the Past 60,000 Years. Science 2008, 322, 252-255. [CrossRef] [PubMed]

137. Garcin, Y.; Junginger, A.; Melnick, D.; Olago, D.O.; Strecker, M.R.; Trauth, M.H. Late Pleistocene-Holocene rise and collapse of Lake Suguta, northern Kenya Rift. Quat. Sci. Rev. 2009, 28, 911-925. [CrossRef]

138. Verschuren, D.; Sinninghe Damsté, J.S.; Moernaut, J.; Kristen, I.; Blaauw, M.; Fagot, M.; Haug, G.H.; van Geel, B.; De Batist, M.; Barker, P.; et al. Half-precessional dynamics of monsoon rainfall near the East African Equator. Nature 2009, 462, 637-641. [CrossRef] [PubMed]

139. Costa, K.; Russel, J.; Konecky, B.; Lamb, H. Isotopic reconstruction of the African Humid Period and Congo Air Boundary migration at Lake Tana, Ethiopia. Quat. Sci. Rev. 2014, 83, 58-67. [CrossRef]

140. Gasse, F. Hydrological changes in the African tropics since the Last Glacial Maximum. Quat. Sci. Rev. 2000, 19, 189-211. [CrossRef]

141. Biasutti, M.; Voigt, A.; Boos, W.R.; Braconnot, P.; Hargreaves, J.C.; Harrison, S.P.; Kang, S.M.; Mapes, B.E.; Scheff, J.; Schumacher, C.; et al. Global energetics and local physics as drivers of past, present and future monsoons. Nat. Geosci. 2018, 11, 392-400. [CrossRef]

142. Gasse, F.; Van Campo, E. A 40,000-yr Pollen and Diatom Record from Lake Tritrivakely, Madagascar, in the Southern Tropics. Quat. Res. 1998, 49, 299-311. [CrossRef]

143. Partridge, T.C.; DeMenocal, P.B.; Lorentz, S.A.; Paiker, M.J.; Vogel, J.C. Orbital forcing of climate over South Africa: A 200,000-year rainfall record from the Pretoria Saltpan. Quat. Sci. Rev. 1997, 16, 1125-1133. [CrossRef]

144. Scott, L. Fluctuations of vegetation and climate over the last 75,000 years in the Savanna Biome, South Africa: Tswaing Crater and Wonderkrater pollen sequences reviewed. Quat. Sci. Rev. 2016, 145, 117-133. [CrossRef]

145. Finney, B.P.; Sholtz, C.A.; Johnson, T.C.; Trumbore, S. Late Quaternary lake-level changes of Lake Malawi. In The Limnology, Climatology and Paleoclimatology of the East African Lakes; Johnson, T.J., Odada, E.O., Eds.; Gordon and Breach: London, UK, 1996; pp. 495-508.

146. Konecky, B.; Russell, J.M.; Johnson, T.C.; Brown, E.T.; Berke, M.A.; Werne, J.P.; Huang, Y. Atmospheric circulation patterns during late Pleistocene climate changes at Lake Malawi, Africa. Earth Planet. Sci. Lett. 2011, 312, 318-326. [CrossRef]

147. Stone, J.R.; Westover, K.S.; Cohen, A.S. Late Pleistocene paleohydrography and diatom paleoecology of the central basin of Lake Malawi, Africa. Palaeogeogr. Palaeoclimatol. Palaeoecol. 2011, 303, 51-70. [CrossRef]

148. Garcin, Y.; Vincens, A.; Williamson, D.; Guiot, J.; Buchet, G. Wet phases in tropical southern Africa during the last glacial period. Geophys. Res. Lett. 2006, 33, L07703. [CrossRef]

149. Broccoli, A.J.; Dahl, K.A.; Stouffer, R.J. Response of the ITCZ to Northern Hemisphere cooling. Geophys. Res. Lett. 2006, 33, L01702. [CrossRef]

150. Collins, J.A.; Schefuß, E.; Heslop, D.; Mulitza, S.; Prange, M.; Tjallingii, R.; Dokken, T.M.; Huang, E.; Mackensen, A.; Schulz, M.; et al. Interhemispheric symmertry of the tropical African rainbelt over the past 23,000 years. Nat. Geosci. 2011, 4, 42-45. [CrossRef]

151. Simon, M.H.; Arthur, K.; Hall, I.R.; Peeters, F.J.C.; Loveday, B.R.; Barker, S.; Ziegler, M.; Zahn, R. Millennial-scale Agulhas Current variability and its implications for salt-leakage through the Indian-Atlantic Ocean Gateway. Earth Planet. Sci. Lett. 2013, 383, 101-112. [CrossRef] 
152. Hansen, M.C.; DeFries, R.S.; Townshend, J.R.G.; Carroll, M.; Dimiceli, C.; Sohlberg, R.A. Global Percent Tree Cover at a Spatial Resolution of 500 Meters: First results of the MODIS Vegetation Continuous Fields Algorithm. Earth Interact. 2003, 7. [CrossRef]

153. Bowen, G.J.; Revenaugh, J. Interpolating the isotopic composition of modern meteoric precipitation. Water Resour. Res. 2003, 39, 1299. [CrossRef]

154. IAEA/WMO Global Network of Isotopes in Precipitation. The GNIP Database. 2015. Available online: https: / nucleus.iaea.org/wiser (accessed on 12 November 2018).

155. Still, C.J.; Powell, R.L. Continental-Scale Distributions of Vegetation Stable Carbon Isotope Ratios. In Isoscapes; Springer: Dordrecht, The Netherlands, 2010; pp. 179-193. [CrossRef]

156. McDermott, F. Palaeo-climate reconstruction from stable isotope variations in speleothems: A review. Quat. Sci. Rev. 2004, 23, 901-918. [CrossRef]

157. Breecker, D.O.; Payne, A.E.; Quade, J.; Banner, J.L.; Ball, C.E.; Meyer, K.W.; Cowan, B.D. The sources and sinks of $\mathrm{CO}_{2}$ in caves under mixed woodland and grassland vegetation. Geochim. Cosmochim. Acta 2012, 96, 230-246. [CrossRef]

158. Gat, J.R.; Klein, B.; Kushnir, Y.; Roether, W.; Wernli, H.; Yam, R.; Shemesh, A. Isotope composition of air moisture over the Mediterranean Sea: An index of the air-sea interaction pattern. Tellus Ser. B Chem. Phys. Meteorol. 2003, 55, 953-965. [CrossRef]

159. Bowen, G.J. Spatial analysis of the intra-annual variation of precipitation isotope ratios and its climatological corollaries. J. Geophys. Res. Atmos. 2008, 113. [CrossRef]

160. Burney, D.A.; Burney, L.P.; Godfrey, L.R.; Jungers, W.L.; Goodman, S.M.; Wright, H.T.; Jull, A.J.T. A chronology for late prehistoric Madagascar. J. Hum. Evol. 2004, 47, 25-63. [CrossRef] [PubMed]

161. Johnson, T.C.; Brown, E.T.; McManus, J.; Barry, S.; Barker, P.; Gasse, F. A High-Resolution Paleoclimate Record Spanning the Past 25,000 Years in Southern East Africa. Science 2002, 296, 113-132. [CrossRef] [PubMed]

162. Lamb, H.F.; Bates, C.R.; Bryant, C.L.; Davies, S.J.; Huws, D.G.; Marshall, M.H.; Roberts, H.M. 150,000-year palaeoclimate record from northern Ethiopia supports early, multiple dispersals of modern humans from Africa. Nat. Sci. Rep. 2018, 8, 1077. [CrossRef] [PubMed]

163. Lyons, R.P.; Scholz, C.A.; Cohen, A.S.; King, J.W.; Brown, E.T.; Ivory, S.J.; Johnson, T.C.; Deino, A.L.; Reinthal, P.N.; McGlue, M.M.; et al. Continuous 1.3-million-year record of East African hydroclimate, and implications for patterns of evolution and biodiversity. Proc. Natl. Acad. Sci. USA 2015, 112, 15568-15573. [CrossRef] [PubMed]

164. Castañeda, I.S.; Werne, J.P.; Johnson, T.C. Wet and arid phases in the southeast African tropics since the Last Glacial Maximum. Geology 2007, 35, 823-826. [CrossRef]

165. Schefuß, E.; Kuhlmann, H.; Mollenhauer, G.; Prange, M.; Pätzold, J. Forcing of wet phases in southeast Africa over the past 17,000 years. Nature 2011, 480, 509-512. [CrossRef] [PubMed]

166. Otto-Bliesner, B.L.; Russell, J.M.; Clark, P.U.; Liu, Z.; Overpeck, J.T.; Konecky, B.; Nicholson, S.E.; He, F.; $\mathrm{Lu}, \mathrm{Z}$. Coherent changes of southeastern equatorial and northern African rainfall during the last deglaciation. Science 2014, 346, 1223-1227. [CrossRef] [PubMed]

167. Pickering, R.; Dirks, P.H.G.M.; Jinnah, Z.; de Ruiter, D.J.; Churchill, S.E.; Herries, A.I.R.; Woodhead, J.D.; Hellstrom, J.C.; Berger, L.R. Australopithecus sediba at 1.977 Ma and Implications for the Origins of the Genus Homo. Science 2011, 333, 1421-1423. [CrossRef] [PubMed]

168. Pickering, R.; Kramers, J.D.; Partridge, T.; Kodolanyi, J.; Pettke, T. U-Pb dating of calcite-aragonite layers in speleothems from hominin sites in South Africa by MC-ICP-MS. Quat. Geochronol. 2010, 5, 544-558. [CrossRef]

(C) 2019 by the authors. Licensee MDPI, Basel, Switzerland. This article is an open access article distributed under the terms and conditions of the Creative Commons Attribution (CC BY) license (http:/ / creativecommons.org/licenses/by/4.0/). 